Review of
ECONOMICS
and
INSTITUTIONS

\title{
Aggregate Earnings and Macroeconomic Shocks: the Role of Labour Market Policies and Institutions
}

\author{
Andrea Bassanini \\ OECD, ERMES and IZA
}

\begin{abstract}
I examine the effect of labour market policies and institutions on the transmission of macroeconomic shocks to the labour market, using both aggregate and industry-level annual data for 23 OECD countries, 23 business-sector industries and up to 29 years. I find that high and progressive labour taxes and generous unemployment benefits amplify labour income fluctuations. By contrast, statutory minimum wages reduce the difference in the sensitivity of wages to aggregate shocks between low-wage and high-wage industries. Dismissal regulations are found to mitigate the impact of shocks on both earnings and employment. Moreover, this mitigation effect is greater in industries where firms have a greater propensity to make staffing changes through dismissals.
\end{abstract}

JEL classification: J21; J31; J60

Keywords: employment fluctuations, business-cycle, EPL, tax wedge, unemployment benefits

This paper draws on unpublished background work for Chapter 3 of the 2011 edition of the OECD Employment Outlook. Nevertheless, the views expressed here are those of the author and cannot be attributed to the OECD or its member countries. Skilful research assistance by Agnès Puymoyen and Sébastien Martin as well as comments from one anonymous referee, Romain Duval, Pascal Marianna, Stefano Scarpetta, Paul Swaim, Ken Swinnerton and, especially, Danielle Venn are gratefully acknowledged. I am also grateful to Ana Lamo, the Eurosystem's Wage Dynamics Network (WDN) and the European Central Bank (ECB) for kindly providing WDN data on wage indexation. Standard caveats apply.

$\triangle$ Address: Andrea Bassanini, OECD, ELS, 2 Rue André Pascal, 75775 Paris Cedex 16. (Phone +33 14524 9032. Email: andrea.bassanini@oecd.org. Web: sites.google.com/site/bassaxsite/home)

\section{Recommended Citation}

Bassanini, A. (2012). Aggregate Earnings and Macroeconomic Shocks: the Role of Labour Market Policies and Institutions. Review of Economics and Institutions, 3(3), Article 1. doi: 10.5202/rei.v3i3.87. Retrieved from http://www.rei.unipg.it/rei/article/view/87 


\section{Introduction}

There is an increasingly large empirical literature that investigates crosscountry differences in the way employment and unemployment react to macroeconomic shocks (Blanchard and Wolfers, 2000, Nickell et al., 2005, Bassanini and Duval, 2006, Porter and Vitek, 2008). Many studies also point to cross-country differences in the resilience of employment to shocks - most prominently between the United States and Continental European countries (Burgess et al., 2000, Balakrishnan and Michelacci, 2001, Amisano and Serrati, 2003, Dustmann et al., 2010, Ormerod, 2010). In this context, previous research suggests that structural policy settings might amplify or mitigate the employment effects of shocks and make them more or less persistent (Blanchard and Wolfers, 2000, Bassanini and Duval, 2006).

By contrast, the literature on cross-country differences in the response of aggregate earnings to shocks is comparatively smaller (see e.g. Balmaseda et al., 2000, Messina et al., 2009, Dustmann et al., 2010, Kandil, 2010). A key issue for workers' well-being, however, is the extent to which cyclical downturns result in fluctuations in labour market earnings - that is the combined effect of changes in employment, hours worked and wages. Indeed, a recession can impact the labour income of employees even if they do not lose their job, by affecting the number of paid hours of work (through lower paid overtime or temporary cuts to working hours) and/or by reducing their real hourly wage (generally by compressing nominal wage growth). In addition, recessions can have long-term consequences on the labour income of employees through the effect on the length of non-employment spells and wage levels at re-employment (see e.g. Jacobson et al., 1993, Farber, 2005, Krebs, 2007, and Schmieder al., 2010). Quantifying the effect of policies and institutions in shaping the costs of a recession for workers involves, at the very least, assessing their effect on all sources of loss of labour income. This is also of crucial importance to the government budget in downturns insofar as reductions in gross labour income are directly reflected in falling government revenues and greater demand for social spending. In order to make some steps in filling this gap, by making use of aggregate and industry-level data, this paper investigates the role for labour market policies and institutions in influencing how aggregate earnings adjust over the cycle and the relative importance of different adjustment margins.

In order to identify the effect of policies and institutions I use both a standard cross-country/time-series approach and an industry-level differencein-difference approach. Using aggregate cross-country/time-series data makes it possible to exploit the large variation in policies across countries and over time and examine general equilibrium effects. Yet, a key problem with aggregate analysis is that it is difficult to control for an exhaustive list of confounding factors. I circumvent this problem by exploiting the fact that cross-country comparable time-series data on earnings and employment are 
available at the industry level and that, while labour market policies and institutions are defined at the aggregate level, the impact of a few of them (notably the minimum wage and employment protection, EP hereafter) is likely to differ across industries. Within this context, I use a differencein-difference strategy in the spirit of Rajan and Zingales (1998). The basic premise is that EP and the minimum wage are more likely to be binding in some industries than others. Therefore, if these policies have an impact on the transmission of aggregate shocks to earnings fluctuations, this impact will be greater in these so-called policy-binding industries. For example, reforms of dismissal regulations are likely to have a greater impact on the labour market adjustment in industries where, in the absence of regulations, firms rely on layoffs to make staffing changes, rather than in industries where internal labour markets or voluntary turnover are more important. We can use these other industries as a control group for EP-binding industries. In following this strategy, we will at worst underestimate the true effect of EP on earnings fluctuations. The same methodology can be followed for the minimum wage, by defining as minimum-wage-binding industries those industries that typically employ low-pay workers - that is, workers for which high minimum wages are more likely to constrain downward wage adjustments.

By looking simultaneously at the adjustment of wages and employment, this paper also complements the micro-literature on wage cyclicality. Estimates based on microdata consistently indicate a greater pro-cyclicality of individual wages than those based on macrodata (see e.g. Abraham and Haltiwanger, 1995; Brandolini, 1995; Devereux, 2001; Devereux and Hart, 2007), particularly for new hires (see Pissarides, 2009, for a survey). Nonetheless, the literature have clearly shown that nominal wages for incumbents tend to be rigid downward (see among others Nickell and Quintini, 2003, Gottschalk, 2005, Dickens et al., 2007, Messina et al., 2010 and the December 2010 special issue on price and wage dynamics on the Scandinavian Journal of Economics). A more infant literature has also related downward wage rigidity with upward wage rigidity: in order to cope with worker resistance to wage cuts, the optimal reaction of firms would be to temper wage increases in boom times (Bewley et al., 2000, Elsby, 2009). The consequence of this literature is that wages might adjust less and more slowly. Institutions, and notably wage bargaining institutions and employment protection legislation are typically considered to explain cross-country differences in wage rigidity patterns (Bertola and Rogerson, 1997, Bertola, 1999, Babecký et al. 2009, 2010).

The paper is divided as follows: Section 1 details the empirical strategy. Section 2 describes the data. Section 3 presents the empirical results. Concluding remarks follows. 


\section{Empirical Strategy}

A very simple and widely-used way to measure the impact of cyclical output fluctuations on a given aggregate variable (e.g. log total earnings) is to measure the covariation of the output gap and the cyclical component of that variable (see e.g. Abraham and Haltiwanger, 1995). Let us consider the following simple multiplicative model:

$$
\log W_{i t}=\theta \log W_{i t}^{*}+\sum_{l} \varphi_{l} O G A P_{i t-l}+\varepsilon_{i t}
$$

where $\log W$ is the $\log$ of total earnings, ${ }^{*}$ indicates its non-cyclical (i.e. trend or potential) component, OGAP is the output gap that is assumed to capture all business-cycle-related macroeconomic shocks, $i$ and $t$ index country and time and $\epsilon$ is an error term capturing shocks that are unrelated to the business-cycle. The non-cyclical component of total earnings is disentangled from the cyclical component through a Hodrick-Prescott (HP) filter (see, Hodrick and Prescott, 1997) 11 Hereafter, we will refer to the noncyclical component of a variable as its trend and to the cyclical component as its gap, noting that the sum of the trend and gap yields the actual value by construction. To the extent that the trend captures all structural long-run determinants of the variable, including e.g. population growth and institutions, and shocks are stationary (with zero mean), $\theta$ can be set equal to 1 and the above equation becomes:

$$
\log W G A P_{i t}=\sum_{l} \varphi_{l} O G A P_{i t-l}+\varepsilon_{i t}
$$

where $\log W G A P$ is the gap of $\log W$. The sum of $\varphi s$ represents the long-run elasticity of fluctuations in $\log W$ to business-cycle fluctuations as measured by the output gap. In this paper we are interested not only to total earnings but also to its components (average hourly wage, total hours worked and/or total dependent employment). I will apply the empirical models presented in the next subsection alternatively to all these variables.

1 HP-filtered series are estimated by minimising a weighted average of the square of the
growth of the trend component and its quadratic difference from the actual series. As
standard for annual data, I set the relative weight of the growth term to 100. One prob-
lem with the HP filter is that it performs poorly around the beginning and the end of
each time series. The Baxter-King filter (Baxter and King, 1999), by "passing" only fre-
quencies between a low and high thresholds (reflecting the idea that business cycles are
fluctuations of a certain frequency), performs better but at the cost of eliminating a few
observations around the endpoints. Usual thresholds for the Baxter-King filter are 2 and
8 years, which is what I use here. In order to preserve sample size, I mainly use the HP
filter in this paper, but all results are qualitatively robust to the use of a Baxter-King filter. 


\subsection{Aggregate Cross-Country/Time-Series Analysis}

As mentioned in the introduction, the goal of this paper is to estimate the impact of labour market institutions in shaping the reaction of aggregate earnings to macroeconomic shocks. In order to assess the amplification/mitigation effects of policies or institutions, the latter are assumed to affect the elasticity of fluctuations to the output gap as specified in equations (1) and (2). More precisely, let us start with the following static model:

$$
\log W_{i t}=\theta \log W_{i t}^{*}+\sum_{k} \varphi_{k}\left(P_{i t}^{k}-\bar{P}^{k}\right) O G A P_{i t}+\text { Other covariates }+\varepsilon_{i t}
$$

where $\log W$ is the logarithm of total earnings, hours worked, or hourly wages, ${ }^{*}$ indicates their respective trend values, OGAP is the output gap, $i$ and $t$ index country and time, respectively, $P$ stands for policies and institutions, indexed by $k$, a bar above a variable indicates its sample average and $\epsilon$ is an error term capturing shocks that are unrelated to the businesscycle. Other covariates include the output gap, country and time dummies, and the level of each included institution (for identification of the interaction terms). ${ }^{2}$ As above, to the extent that the trend captures all structural long-run determinants of the dependent variable and shocks are stationary, $\theta$ can be set equal to 1 and the above equation becomes:

$$
\log W G A P_{i t}=\sum_{k} \varphi_{k}\left(P_{i t}^{k}-\bar{P}^{k}\right) O G A P_{i t}+\text { Other covariates }+\varepsilon_{i t}
$$

where $\log W G A P$ is the gap of $\log W$. The hypothesis $\theta=1$ can be easily tested and in fact is never rejected in the specifications presented in this paper. Insofar as institutions are included as deviations from their sample means, $\varphi_{0}$ captures the elasticity of the dependent variable with respect to the output gap for an "average country", assuming no lagged effects. The model can, however, be easily extended to include lagged effects. A positive estimated sign of $\varphi_{k}$ for a given policy $P_{k}$ implies that the policy significantly amplifies output shocks, while a negative sign means that the policy exerts a smoothing effect on output fluctuations. ${ }^{3}$ The ratio $\varphi_{k} / \varphi_{0}$ gives a quantitative assessment of the proportional increase (if positive) or decrease (if

${ }^{2}$ Following a standard approach in aggregate unemployment regressions (see for example Biagi and Lucifora, 2008), in order to capture unusually large swings in Sweden and Finland at the beginning of the 1990s, I include specific dummies for Sweden and Finland in 1991-1992 and the subsequent period.

${ }^{3}$ In principle amplification (and persistence - see below) parameters can be different in expansionary and contractionary stages of the cycle. However, in all the specifications considered in this paper, statistical tests can never reject the insignificance of possible differences. For this reason, this issue is not explored further in this paper and is left for future research. 
negative) of the elasticity to the output gap if the policy $P_{k}$ is raised by one unit from the OECD average.

An adverse shock might not only compress earnings and reduce employment. Its effects might also persist over time, and the degree of persistence is likely to be affected by policies and institutions. In order to assess amplification versus persistence effects of shocks, a dynamic version of the baseline model described above is needed. The simplest one is the following errorcorrection model:

$$
\begin{aligned}
\Delta \log W_{i t} & =-\phi\left(\log W_{i t-1}-\theta \log W_{i t-1}^{*}\right)+\kappa \Delta \log W_{i t}^{*}+ \\
& +\sum_{k} \varphi_{k}\left(P_{i t}^{k}-\bar{P}^{k}\right) O G A P_{i t}+\text { Other covariates }+\varepsilon_{i t}
\end{aligned}
$$

where $\phi$ is a non-negative coefficient that captures persistence mechanisms (the greater it is, the less persistence). Under the same assumptions as above, this can be rewritten as:

$$
\begin{aligned}
\Delta \log W G A P_{i t}= & -\phi\left(\log W G A P_{i t-1}\right)+b \Delta \log W_{i t}^{*}+\sum_{k} \varphi_{k}\left(P_{i t}^{k}-\bar{P}^{k}\right) \times \\
& \times O G A P_{i t}+\text { Other covariates }+\varepsilon_{i t},
\end{aligned}
$$

with $b=\kappa-1$ and $\theta=1$. $\phi$ can also be modeled as dependent on institutions:

$$
\phi=\gamma_{0}+\sum_{k} \gamma_{k}\left(P_{i t}^{k}-\bar{P}^{k}\right)
$$

where $\gamma_{0}$ captures the persistence of the average country (the smaller its value, the greater the degree of persistence). From a qualitative point of view, the interpretation of the $\gamma$ coefficients is simple: a negative value $\gamma_{k}$ indicates that a deviation of the policy $P_{k}$ from the sample average is estimated to increase persistence. From a quantitative point of view, the interpretation is somewhat more complex. The equation above is justified by a model in which, after a one-period transitory shock, if no other shock occurs, the dependent variable goes back to its trend level following an exponential time path:

$$
\log W G A P_{i t}-\log W G A P_{i 0}=-\left(1-e^{-\lambda t}\right)\left(\log W G A P_{i 0}\right),
$$

where $\lambda$ is a parameter describing the speed of convergence to the equilibrium trend. Since the empirical model above is estimated on annual data, it follows that $\lambda=-\ln (1-\phi)$. Persistence is typically measured in terms of the half-life $H$ of a shock - that is the number of years required to reduce the initial impact of a shock by $50 \%-$ which is equal to $\ln (2) / \lambda$. Therefore the impact on the half-life of a shock of the increase in the policy $X_{k}$ from 
the OECD average can be written, in the case of a discrete policy variation, in terms of proportional effect as:

$$
\frac{\Delta H / H}{\Delta X_{k}}=\frac{\log \left(1-\gamma_{0}\right)}{\log \left(1-\gamma_{0}-\gamma_{k}\right)}-1
$$

Insofar as certain policies might have opposite amplification and persistence effects, these two effects must be combined in some way in order to assess the consequences of policy actions in terms of labour-income smoothing. In turn this requires making assumptions about the discount rate and, if individual labour-income risk is not insurable, the degree of risk aversion. Let us assume a discount rate equal to $\delta$ and linear utility (that is no risk aversion), and consider the total cumulated impact, denoted $C_{0}$, of a shock resulting in a one-period transitory deviation of output from its trend by one percentage point. Its actual value in the average country at the time of the shock can be computed as:

$$
C_{0}=\int_{0}^{+\infty} \varphi_{0} e^{-\left(\lambda_{0}+\delta\right) t} d t=\frac{\varphi_{0}}{\lambda_{0}+\delta}
$$

where $\lambda_{0}=-\ln \left(1-\gamma_{0}\right)$ and $\gamma_{0}$ and $\varphi_{0}$ are defined as above. The overall effect of a policy on volatility can be measured in this context. Denote the estimated proportional effect of a one unit change of a given policy on $\varphi_{0}$ and $\lambda_{0}$, as $\xi$ and $\zeta$, respectively. In other words, for a one-point increase in that policy, the immediate effect of a one percentage point shock on the dependent variable will be $(1+\xi) \varphi_{0}$, while the half-life of the effects of that shock will be $\ln (2) /(1+\zeta) \lambda_{0}$. The cumulated impact $C$ of the shock after the policy reform will be:

$$
C=\int_{0}^{+\infty} \varphi_{0}(1+\xi) e^{-\left(\lambda_{0}(1+\zeta)+\delta\right) t} d t=(1+\xi) \frac{\varphi_{0}}{(1+\zeta) \lambda_{0}+\delta} .
$$

The overall impact of the policy on the cumulated effect of the shock, expressed as a proportion of the cumulated effect of that shock for the average country - that is $\left(C-C_{0}\right) / C_{0}$, can be written as:

$$
c=(1+\xi) \frac{\lambda_{0}+\delta}{(1+\zeta) \lambda_{0}+\delta}-1
$$

In other words in the case of an adverse shock, $c$ multiplied by 100 gives an estimate of the difference (in percentage points) between the total cost of that shock in a country that has the same institutions as in the average country except for a one-unit greater level of the policy of interest and the cost of that shock in the average country. To the extent that all these parameters, with the exception of the discount rate, are obtained from the estimated 
equation, a confidence interval for $c$ can be derived, and related statistical hypotheses tested.

For a policy with significant effects on both amplification/mitigation and persistence, two observations are however in order. First, equations (6) and (7) show that the greater the discount rate, the smaller the importance of the persistence effect of a policy as regards total costs/benefits of shocks. Moreover, second, the higher the degree of risk aversion, the greater the demand for consumption smoothing and the greater the weight of the mitigation effect of the policy in the determination of the total costs of adverse shocks.

One key identification problem in estimating equations (4) and (5) is that policies might be endogenous and, in particular, may be adapted during severe recessions. However, in the sample, the fluctuation of policies over time is much smaller than their variance across countries. Insofar as the effect of policies is identified also through their cross-country variation, reverse causality issues appear somewhat minor. By contrast, as in standard aggregate cross-country/time-series analyses, it is more difficult to control for an exhaustive list of confounding factors. In fact, due to the high correlation across institutions (see for example Bassanini and Duval, 2009), it is quite likely that a number of institutions that are omitted from the above equations will be simultaneously correlated with included policies and affect the transmission of macroeconomic shocks to the labour market. In order to reduce these concerns, I also use an industry-level difference-indifference approach in the case of specific policies, such as employment protection (EP hereafter) and the minimum wage, whose effect is likely to differ across industries. This approach is described in the following subsection.

\subsection{Industry-Level Difference-in-Difference Analysis}

In the industry-level difference-in-difference approach, originally suggested by Rajan and Zingales (1998), the idea is to look at within-country industry differences in the effect of an aggregate policy variable. The identifying assumption is that if a policy $P$ has an impact on an economic variable, this impact - whatever its sign - is greater in industries where $P$ is more likely to be binding - hereafter called "policy-binding" (or P-binding) industries. I apply this idea to policy determinants of the transmission of macroeconomic shocks to labour market fluctuations. For example, EPbinding industries will be those where firms typically need to lay off workers to restructure their operations in response to changes in technologies or product demand and where, therefore, high firing costs are likely to slow the pace of reallocation of resources. In these industries, one can expect that EP has the greatest impact, if any, on cyclical fluctuations. By contrast, in industries where firms can restructure through internal adjustments or by relying on natural attrition of staff, changes in EP for open-ended con- 
tracts can be expected to have little impact. Following Bassanini al. (2009), I use average dismissal rates by industry in the United States, the least regulated OECD country, as a benchmark to measure the layoff propensity of each industry in the absence of regulation. Obviously, as this benchmark would not be pertinent in the case of regulations on hiring of temporary workers, I use only an indicator of dismissal restrictions in the case of employees under open-ended contracts (see the next section). Similarly, in the case of the minimum wage, the estimation is based on the assumption that changes in minimum wages have a greater impact on wage and earnings cyclicality in industries that are more heavily reliant on low-wage labour. In this case, as suggested by Bassanini and Venn (2007), I identify low-wage industries based on the incidence of low-wage workers by industry in one specific country, the United Kingdom, prior to the introduction of statutory minimum wages in that country in 1999, when the de facto minimum wage can be assumed to be arbitrary small.

The advantage of this estimation strategy is that it controls for policies or institutions that influence cyclical fluctuations in the same way in all industries. More precisely, all factors and policies that can be assumed to have, on average, the same effect on the dependent variable in policy-binding industries as in other industries can be controlled for by country-by-time dummies. In practice, the same models as in the previous subsection can be used to estimate the elasticity of industry-specific fluctuations to aggregate shocks. In that case, in equations (1) to (5), $\log W G A P$ will be an industry-bycountry-specific time-varying variable. Nevertheless, to the extent that we want to estimate the reaction to aggregate shocks rather than to industryspecific reallocation shocks, OGAP must be the aggregate output gap and will therefore remain a country-specific time-varying variable. By contrast, the effect of policies on the elasticity of $\log W G A P$ to OGAP will be assumed to be industry-specific, that is I will estimate:

$$
\begin{aligned}
\log W G A P_{i j t}=\alpha B_{j} P_{i t} & +\beta B_{j} O G A P_{i t}+\varphi B_{j}\left(P_{i t}-\bar{P}\right) O G A P_{i t}+ \\
& +X_{i j t} \delta+\eta_{i t}+\eta_{j t}+\eta_{i j}+\varepsilon_{i j t}
\end{aligned}
$$

where $i, j$ and $t$ index country, industry and time, respectively, $P$ stands for the policy of interest, a bar above a variable indicates its sample average, $B$ is the benchmark used to classify industries, ${ }^{5} X$ stands for additional covariates (including other interactions), $\eta s$ are bi-dimensional fixed effects (estimated by including the corresponding bi-dimensional dummies in the spec-

${ }^{4}$ Draca al. (2011) use a similar identification strategy at the firm level.

5 That is, either the industry-specific US dismissal rate proxying the dismissal propensity of an industry in the absence of regulation, in the case of EP, or the share of low-pay workers in the UK prior 1999, proxying the natural propensity to employ low-paid workers in the absence of a minimum wage. 
ification) that capture all aggregate effects as well industry-specific trends $\mathrm{s}^{6}$ and $\epsilon$ is an error term capturing idiosyncratic shocks that are unrelated to the business cycle. The parameter of interest is $\varphi$. A positive sign for $\varphi$ would suggest that output-gap fluctuations result in bigger fluctuations of the dependent variable in $P$-binding industries when $P$ is high. Such a finding, given the identification assumptions made above, would imply an amplification effect of $P$. By contrast, a negative sign would imply a mitigation effect of $P$. A reasonable estimate of the absolute effect of a one-unit increase of $P$ on the elasticity to the output gap for an average industry of an average country is given by $\varphi$ multiplied by the average value of the benchmark $B$. This relies on the reasonable assumption that the effect of $P$ is 0 in an hypothetical industry for which $B$ is equal to 0 . Moreover, if $\beta$ is precisely estimated, the ratio $\varphi / \beta$ multiplied by 100 would provide an estimate of the percentage effect of $P$ on the elasticity of fluctuations in the dependent variable with respect to the output gap, in the same way as $\varphi_{k} / \varphi_{0}$ in the previous subsection.7

The same framework can be used to study the effect of $P$ on persistence, by assuming that persistence is likely to be greater (whatever its sign) in $P$-binding industries. In that case, the equivalent of equation (5) is:

$$
\begin{aligned}
\Delta \log W G A P_{i t} & =-\phi\left(\log W G A P_{i t-1}\right)+b \Delta \log W_{i t}^{*}+\left(\beta+\varphi\left(P_{i t}-\bar{P}\right)\right) \times \\
& \times B_{j} O G A P_{i t}+\text { Other covariates }+\varepsilon_{i j t}
\end{aligned}
$$

where

$$
\phi=\gamma_{0}+\gamma_{P}\left(P_{i t}-\bar{P}\right)+\gamma_{B} B_{j}+\gamma_{P B} B_{j}\left(P_{i t}-\bar{P}\right) .
$$

The parameter of interest is $\gamma_{P B}$. A negative sign of $\gamma_{P B}$ would suggest that dismissal regulations increase persistence more in $P$-binding industries than in other industries, which, given the identification assumptions made above, would imply that the policy $P$ raises aggregate persistence. The effect on the half-life and the cumulated impact of a shock can be obtained in the same way as in the previous subsection.

Finally, policies and institutions might affect the magnitude of fluctuations in the aggregate output gap. Using this difference-in-difference methodology, it is possible to identify the direct effect of $P$ on output fluctuations: in fact, if $P$ had an impact on value-added fluctuations, one would expect this effect to be greater in P-binding industries. For example, suppose that stringent EP dampens GDP fluctuations, then one would expect EP to reduce the difference between EP-binding and other industries in the elasticity of fluctuations of industry-specific value-added to the aggregate output gap.

\footnotetext{
6 Country-by-industry effects are less justified and are included only in sensitivity analyses.

7 Assuming that $\alpha=0$ and is precisely estimated. This condition always holds at standard confidence levels in the specifications estimated in this paper (likely because log WGAP has close-to-zero mean by construction).
} 
The same argument can be made for persistence. This would imply that the sign of the effects of EP on aggregate GDP fluctuations can be identified by substituting the logarithm of the industry-specific value-added gap for the dependent variable in equations (8) and (9) above.

\section{Data}

I draw value added, total earnings, average hourly wages, total hours worked and total employment from the EU KLEMS database (www.euklems.net), except for Norway, for which data come from the OECD STAN Database. Both databases are designed to provide cross-country comparable data at the industry-level that are consistent with national accounts. This allows me to have comparable data on these variables for 23 business-sector industries, 23 countries and up to 22 years (1986-2007) ${ }^{8}$ I obtain aggregate data on these economic variables by summing them over business sector industries, which allows me to have aggregate time series that span over 29 years (1979-2007). Labour market data refer to wage and salary employees, except in the case of Norway, however, where data refer to total employment. Earnings and wage data are deflated based on private consumption deflators (drawn from the OECD EO database), which is preferred to the consumer price index because it is available for a larger number of countries. Results presented in the paper are however robust to changes in the deflator. Real value added is obtained by deflating nominal value added in each industry with the industry-specific double deflator. The aggregate output gap comes from the OECD EO database and refers to the whole economy. In the case of Korea, due to missing data, the output gap is obtained by filtering real GDP through an HP filter with standard parameters. 9

In terms of policies and institutions, I focus in this paper on the standard set of policy and institutional variables (henceforth, institutions for brevity) that have been widely used in previous empirical analyses of unemployment (see e.g. Blanchard and Wolfers, 2000; Nickell et al., 2005; Bassanini and Duval, 2006). These are: the tax wedge between labour cost and takehome pay (for a single-earner couple with two children, at average earnings levels); a summary measure of unemployment benefit generosity (an average of gross replacement rates across various earnings levels, family situations and durations of unemployment); the degree of stringency of employment protection (EP) and its subcomponent on regulations for individual dismissals of permanent workers (EPR hereafter); the ratio of the statutory

8 The list of industries is reported in Table A1. Available countries are Australia, Austria, Belgium, Canada, Czech republic, Denmark, Finland, France, Germany, Greece, Ireland, Italy, Japan, Korea, the Netherlands, Norway, Poland, Portugal, Slovak Republic, Spain, Sweden, the United Kingdom and the United States

9 Results are robust to using HP filtering of GDP time series to derive output gaps for all countries. 
minimum wage to median wage of full-time workers, ${ }^{10}$ collective bargaining coverage rates; and the degree of centralisation/co-ordination of wage bargaining, a proxy for the concept of "corporatism" which has received widespread attention in the comparative political economy literature. I use two mutually exclusive measures of corporatism: one is drawn from Bassanini and Duval (2006) and takes only three values (low, intermediate and high), while the other is drawn from the ICTWSS database and is more detailed. I also include in most specifications the average degree of stringency of product market regulation (PMR) across seven non-manufacturing industries 11

In the case of the tax wedge and of unemployment benefits, more interesting indicators are available for a shorter period and I use their country average in sensitivity analyses. In particular, OECD data on net replacement rates are available since 2001. Similarly, data on marginal tax rates are available for eight income levels and family situations since 2000. These rates refer to the marginal tax of the principal earner in the following situations: single person at $167 \%$ of average earnings and no child; single person at $100 \%$ of average earnings and no child; two-earner married couple, one at $100 \%$ of average earnings and the other at $33 \%$, with no child; twoearner married couple, one at $100 \%$ of average earnings and the other at 67 $\%$, with two children; two-earner married couple, one at $100 \%$ of average earnings and the other at 33\%, with two children; single person at $67 \%$ of average earnings, with two children; one-earner married couple at $100 \%$ of average earnings, with two children; and single person at $67 \%$ of average earnings, no child. The simple average of all eight marginal rates yields a rough indicator of the level of average marginal tax rates on labour income. Furthermore, I will define hereafter the simple average of the first four in the above list as marginal tax wedge on "relatively high income levels".

Two industry benchmarks are used for the difference-in-difference analysis: the industry-specific US dismissal rate, which is drawn from Bassanini and Garnero (2012) ${ }^{12}$ and is derived from various waves of the CPS Displaced Workers Supplement; and the industry-specific share of low-paid workers in the United Kingdom prior to the introduction of the minimum

${ }^{10}$ Comparable time-series on minimum wages are available for only the subset of countries where they are imposed by law or regulation, rather than being set by collective bargaining among social partners. These countries are Australia, Belgium, Canada, Czech republic, France, Greece, Japan, Korea, the Netherlands, Poland, Portugal, Slovak republic, Spain, the United Kingdom and the United States.

11 This PMR indicator is used because it is available over a long time-series for many OECD countries, unlike the economy-wide indicator which covers only 3 years in the period 1998-2008. One drawback is that changes in the PMR indicator for non-manufacturing industries do not incorporate all aspects of regulatory reforms that have been undertaken by a number of OECD countries in the past decades, such as administrative reforms affecting all sectors. As a result, the effects of regulatory reforms may not be fully captured by the econometric estimates presented in this paper.

${ }^{12}$ Data available at https://sites.google.com/site/bassaxsite/home/files/BGdata.zip. 
wage in 1999 obtained from quarterly UK Labour Force Surveys as the average share of low-pay workers in each industry over all available quarters between 1994 and 1998. ${ }^{13}$ Both measures appear to be stable over time ${ }^{14}$

More details on variable construction and sources and descriptive statistics are reported in the Annex. Other specific data, used as additional controls in certain specifications, are discussed in the next sections.

\section{Earnings Fluctuations}

\subsection{Aggregate Analysis}

To begin, I estimate the extent to which selected policies and institutions appear to amplify or mitigate the impact of output shocks on total earnings, average wages and total hours worked by fitting a simple static cross-country/time-series model (cf. equation (4)) ${ }_{15}^{15}$ Results of this estimation exercise are presented in Table 1. The first line reports elasticities at the sample average ${ }^{16}$ For a country with average institutions, both average hourly wages and total hours of work appear to fluctuate procyclically, resulting in strong procyclicality of total earnings (with an average elasticity of 1.05). However, the elasticity of wages (0.14) is much smaller than the elasticity of hours $(0.92){ }^{17}$

${ }^{13}$ In each quarter, low-paid workers are defined as those with gross hourly wages less than two-thirds of the median wage of the quarter for the whole economy.

14 Stability of the industry distribution of US dismissal rates is discussed in Bassanini et al. (2009). As regards the UK share of low-pay workers, Fisher and Spearman's correlation coefficients between any pair of quarters are never smaller than 0.95 .

${ }^{15}$ Institutions are included both in levels and in interaction with the output gap but, as expected, coefficients of levels are insignificant in all specifications.

${ }^{16}$ Since institutions are included in deviation from the sample mean, the coefficient on the output gap shows average elasticities.

17 This difference is, by and large, the result of the exclusion of lagged effects. In fact, OECD (2011) shows that if longer lags are allowed in the specification, the elasticity of wages to output shocks becomes much greater. Two reasons might explain the small contribution of contemporaneous wage fluctuations. First, there is evidence that the sensitivity of employment to downturns is greater among low-paid workers (youth, low-skilled and temporary workers, see e.g. Abraham and Haltiwanger, 1995, OECD, 2010, Heathcote et al., 2010, Robin, 2011). Therefore, given the size of the employment elasticity, the low aggregate wage elasticity might reflect a compositional effect, with the average hourly wage remaining relatively unchanged when adverse shocks drive a large numbers of youth, low-paid and temporary workers into unemployment. Second, when contracts cannot be re-negotiated each year, any short-run measure of the cyclicality of real wages tends to be dominated by changes in the consumption price deflator (see e.g. Messina et al., 2009). Moreover, even when contracts are frequently negotiated, there is evidence that nominal wages tend to be rigid both downward and upward, so that adjustments are delayed for several periods, particularly in times of low inflation when these rigidities bind (see in particular Elsby, 2009). This issue is not analysed further here, but must be kept in mind in interpreting the results. 
Table 1 - Institutions and Shock Amplification/Mitigation

\begin{tabular}{|c|c|c|c|c|c|c|}
\hline & \multicolumn{2}{|c|}{ Total earning gap } & \multicolumn{2}{|c|}{ Hourly wage gap } & \multicolumn{2}{|c|}{ Total hours worked gap } \\
\hline & (1) & (2) & (1) & (2) & (1) & (2) \\
\hline Output gap & $\begin{array}{r}1.055^{* * *} \\
(11.991)^{-10}\end{array}$ & $\begin{array}{c}1.051^{* * *} \\
(11.703)^{2}\end{array}$ & $\begin{array}{l}0.139^{* *} \\
(2.441)\end{array}$ & $\begin{array}{l}0.136^{* *} \\
(2.363)\end{array}$ & $\begin{array}{c}0.916^{* * *} \\
(14.072)\end{array}$ & $\begin{array}{r}0.915^{* * *} \\
(13.894)\end{array}$ \\
\hline EP & $\begin{array}{c}-0.1944^{*} \\
(1.922)\end{array}$ & $\begin{array}{l}-0.196 * \\
(1.872)\end{array}$ & $\begin{array}{r}-0.059 \\
(0.853)\end{array}$ & $\begin{array}{r}-0.081 \\
(1.075)\end{array}$ & $\begin{array}{r}-0.136 \\
(1.404)\end{array}$ & $\begin{array}{r}-0.115 \\
(1.150)\end{array}$ \\
\hline Average tax wedge & $\begin{array}{l}0.032 \text { *** } \\
(3.302)\end{array}$ & $\begin{array}{l}0.032 * * * \\
(3.172)\end{array}$ & $\begin{array}{l}0.022^{* * *} \\
(2.835)\end{array}$ & $\begin{array}{l}0.021 * * * \\
(2.879)\end{array}$ & $\begin{array}{r}0.012 \\
(1.513)\end{array}$ & $\begin{array}{r}0.011 \\
(1.324)\end{array}$ \\
\hline PMR & $\begin{array}{r}0.034 \\
(0.416)\end{array}$ & $\begin{array}{r}0.039 \\
(0.477)\end{array}$ & $\begin{array}{r}0.009 \\
(0.165)\end{array}$ & $\begin{array}{r}0.012 \\
(0.226)\end{array}$ & $\begin{array}{r}0.026 \\
(0.422)\end{array}$ & $\begin{array}{r}0.027 \\
(0.455)\end{array}$ \\
\hline Bargaining coverage & $\begin{array}{l}-0.008 * \\
(1.687)\end{array}$ & $\begin{array}{r}-0.007 \\
(1.431)\end{array}$ & $\begin{array}{r}0.000 \\
(0.068)\end{array}$ & $\begin{array}{r}-0.000 \\
(0.050)\end{array}$ & $\begin{array}{l}-0.008^{* *} \\
(2.088)\end{array}$ & $\begin{array}{l}-0.007^{*} \\
(1.736)\end{array}$ \\
\hline ARR & $\begin{array}{l}0.023 \text { *** } \\
(3.329)\end{array}$ & $\begin{array}{l}0.021 \text { *** } \\
(3.345)\end{array}$ & $\begin{array}{r}-0.006 \\
(1.000)\end{array}$ & $\begin{array}{r}-0.005 \\
(1.038)\end{array}$ & $\begin{array}{l}0.029 * * * \\
(5.278)\end{array}$ & $\begin{array}{l}0.025^{* * *} \\
(5.789)\end{array}$ \\
\hline Corporatism (BD) & $\begin{array}{r}-0.050 \\
(0.484)\end{array}$ & & $\begin{array}{r}0.059 \\
(0.843)\end{array}$ & & $\begin{array}{r}-0.110 \\
(1.293)\end{array}$ & \\
\hline Corporatism (ICTWSS) & & $\begin{array}{c}-0.023 \\
(0.398)\end{array}$ & & $\begin{array}{r}0.042 \\
(1.093)\end{array}$ & & $\begin{array}{r}-0.065 \\
(1.475)\end{array}$ \\
\hline Level effect of institutions & Yes & Yes & Yes & Yes & Yes & Yes \\
\hline Country dummies & Yes & Yes & Yes & Yes & Yes & Yes \\
\hline Time dummies & Yes & Yes & Yes & Yes & Yes & Yes \\
\hline Obsrevations & 449 & 449 & 449 & 449 & 449 & 449 \\
\hline R-squared & 0.654 & 0.652 & 0.225 & 0.224 & 0.702 & 0.701 \\
\hline
\end{tabular}

Note: In the first row the table reports the elasticity to the output gap for each dependent variable, estimated at the sample average of each institution. The other rows report the estimated effect of a one unit change of each institution on this elasticity. The term gap indicates the log difference between actual and trend values. EP: Employment Protection, measured on a 0-6 scale. PMR: Product Market Regulation (time-varying index), measured on a 0-6 scale. Two mutually exclusive measures of corporatism are included: BD: Bassanini and Duval index, measured on a 1-3 scale; ICTWSS: ICTWSS index measured on a 0-5 scale. All other variables are measured in percentages. ARR: Average gross unemployment benefit replacement rate. Absolute values of robust t-statistics in parentheses. ${ }^{* * *},{ }^{* *},{ }^{*}$ : statistically significant at the $1 \%, 5 \%$ and $10 \%$ level, respectively.

In the other lines, Table 1 shows baseline aggregate estimates of the amplification/mitigation effects of included institutions ${ }^{18}$ A positive coefficient implies that the policy significantly amplifies output shocks, while a negative sign means that the policy exerts a smoothing effect on output fluctuations. The tax wedge and the generosity of unemployment benefits unambiguously amplify the impact of output-gap fluctuations on total annual earnings. Taken at face value, estimates imply that a 5 percentage-point increase in average replacement rates - that is, about one standard deviation of the distribution, considering only time series variation - from the OECD average raises the elasticity of the total earnings gap to the output gap by between 0.10 and 0.12 (that is, about a 10\% increase), depending on the specification.

Consistent with previous findings (Blanchard and Wolfers, 2000, Bassanini and Duval, 2006), this effect appears to be entirely due to the fact that, ceteris paribus, the employment impact of shocks tends to be larger in countries where unemployment benefits are more generous, while unemployment benefits do not appear to affect wage cyclicality 19

${ }^{18}$ In order to preserve sample size, statutory minimum wages, which are available only for few countries, are not included in the specification. I perform a specific analysis of the minimum wage in Section 4.3.

${ }^{19}$ Some caution is in order here because, due to composition effects (see above), the effect of 
Two mechanisms might explain the amplification effect of benefit generosity on unemployment fluctuations. First, a number of empirical studies suggest that longer durations of generous benefits tend to reduce job-search effort and make the unemployed more choosy about job offers, thereby lengthening the duration of unemployment spells (see e.g. OECD, 2006; Boeri and van Ours, 2008 for surveys), although a few recent studies have questioned these results. ${ }^{20}$ Statistically, this would imply that in the year in which an adverse shock occurs, those who become redundant would remain in the unemployment pool longer, thereby dampening further average employment in that year (and possibly in subsequent years). Second, generous unemployment benefits might reduce workers' resistance to job loss, making them less inclined to challenge dismissals in courts. In fact, Bassanini et al. (2010) show that dismissals leading to unemployment spells are more common in countries with generous unemployment benefits.

Gross replacement rates are used for reasons of time-series availability but net rates would be more meaningful from a theoretical point of view. If an interaction between the 2001-2007 country average of net replacement rates and the output gap is also included, the effect of gross rates becomes insignificant while that of net rates is significant at the 1\% level (see Table 2). This suggests, not surprisingly, that net rather than gross unemployment benefits are responsible for the amplification of business-cycle fluctuations.

By contrast, the effect of the average tax wedge on labour income appears to be essentially due to its role in amplifying gross wage fluctuations, while no significant impact on employment fluctuations is detected. One possible explanation of this finding could be that average tax wedges are higher in countries where marginal tax wedges are more progressive. In turn, progressive labour taxes make labour supply more inelastic and/or the wage-setting curve steeper (see e.g. Guo and Lansing, 1998; Dromel and Pintus, 2008), at least when the latter is defined in terms of gross wages, thereby facilitating wage adjustments (and, possibly, restraining employment adjustments) whenever firms need to compress unit labour costs. In

an institution on the elasticity of wage fluctuations might be biased whenever the same institution has a strong effect on the elasticity of employment adjustments.

${ }^{20}$ Recent findings suggest that one needs to be cautious about the interpretation of the empirical relationship between benefit generosity and the duration of unemployment spells. For example, using Austrian data, Card et al. (2007) argue that unemployment exit spikes at benefit exhaustion are mainly due to leaving the unemployment system and becoming inactive rather than to job-finding. Using US time-use data, Krueger and Mueller (2010) show that there is not much difference in average job-search effort between UI eligible and non-eligible job seekers, but the profile of job-search intensity of the former depends on time to benefit exhaustion. Moreover, the effect of unemployment insurance on search effort seems to be confined only to those job seekers that are liquidity-constrained, whom UI enables to smooth consumption and thus reduces the pressure to rush back to work (Chetty, 2008). By contrast, those with access to a secondary income source are more likely to maintain consumption during a spell of unemployment and thus are less responsive to unemployment benefits. 
Table 2 - Institutions and Amplification/Mitigation of Shocks, Additional Results on Unemployment Benefits and the Tax Wedge

\begin{tabular}{|c|c|c|c|c|c|}
\hline \multicolumn{3}{|c|}{$\begin{array}{l}\text { Panel A. Amplification effect of unemployment benefits } \\
\text { on the total earnings gap }\end{array}$} & \multicolumn{3}{|c|}{$\begin{array}{l}\text { Panel B. Amplification effect of the tax wedge on the hourly } \\
\text { wage gap }\end{array}$} \\
\hline & (1) & (2) & & (1) & (2) \\
\hline Output gap & $\begin{array}{r}1.061^{* * *} \\
(12.081)\end{array}$ & $\begin{array}{l}1.06^{* * *} \\
(11.791)\end{array}$ & Output gap & $\begin{array}{l}0.104^{*} \\
(1.850)\end{array}$ & $\begin{array}{l}0.105^{*} \\
(1.843)\end{array}$ \\
\hline ARR (gross) & $\begin{array}{r}0.013 * \\
(1.743)\end{array}$ & $\begin{array}{r}0.011 \\
(1.500)\end{array}$ & Average tax wedge & $\begin{array}{r}0.005 \\
(0.751)\end{array}$ & $\begin{array}{r}0.006 \\
(0.923)\end{array}$ \\
\hline ARR (net) & $\begin{array}{l}0.013 * * * \\
(2.631)\end{array}$ & $\begin{array}{l}0.013^{* *} \\
(2.521)\end{array}$ & $\begin{array}{l}\text { Marginal tax wedge on } \\
\text { high incomes }\end{array}$ & $\begin{array}{l}0.041^{* * *} \\
(4.452)\end{array}$ & $\begin{array}{l}0.041 * * * \\
(4.407)\end{array}$ \\
\hline Country dummies & Yes & Yes & Country dummies & Yes & Yes \\
\hline Time dummies & Yes & Yes & Time dummies & Yes & Yes \\
\hline Observations & 449 & 449 & Observations & 449 & 449 \\
\hline R-squared & 0.659 & 0.657 & R-squared & 0.263 & 0.263 \\
\hline
\end{tabular}

Note: the table reports the estimated effect of the output gap on each dependent variable at the sample average of each institution as well as the effect of a change of each institutions on this effect. The term gap indicates the log differences between actual and trend values. : ARR: Average unemployment benefit replacement rate; net rates are 2001-2007 averages. The marginal tax wedge on high income is the simple average of the marginal tax rate of the principal earners in the four following situations: single person at $167 \%$ of average earnings and no child; single person at $100 \%$ of average earnings and no child; two-earner married couple, one at $100 \%$ of average earnings and the other at $33 \%$, with no child; and two-earner married couple, one at $100 \%$ of average earnings and the other at $67 \%$, with two children. In addition this tax wedge is averaged over 2000-2007. All specifications include the institutions reported in Table 1 as well as their interaction with the output gap. The BD and ICTWSS indexes of corporatism are used in Column 1 and 2, respectively. All variables are measured in percentages. Absolute values of robust t-statistics in parentheses. ${ }^{* * *},{ }^{* *},{ }^{*}$ : statistically significant at the $1 \%, 5 \%$ and $10 \%$ level, respectively.

this interpretation, the effect of the average tax wedge would reflect the impact of the marginal tax wedge, which is omitted from the main empirical specifications due to lack of data on marginal tax rates for the whole time period under examination. This explanation is supported by the strong correlation between average tax wedge and the marginal tax wedge on relatively high income levels in the eight years for which both are available (correlation coefficient 0.64 ). I therefore test this explanation by including in the regressions, as an additional covariate, the interaction between the output gap and country-specific averages of the indicator of the marginal tax rate for higher income levels computed for the period for which it is available. Consistent with the above interpretation, the marginal tax wedge on relatively high income appears, in this specification, to amplify the wage effect of a shock and conditional on the inclusion of the marginal rate, the estimated coefficient of the interaction between the output gap and the average tax wedge becomes insignificant (Table 2, Panel B) ${ }^{21}$

$\overline{21}$ The estimated coefficients for both the tax wedge and the replacement rate are robust to the exclusion of other co-variates as well as the exclusion of countries one-by-one (results available from the author upon request). 


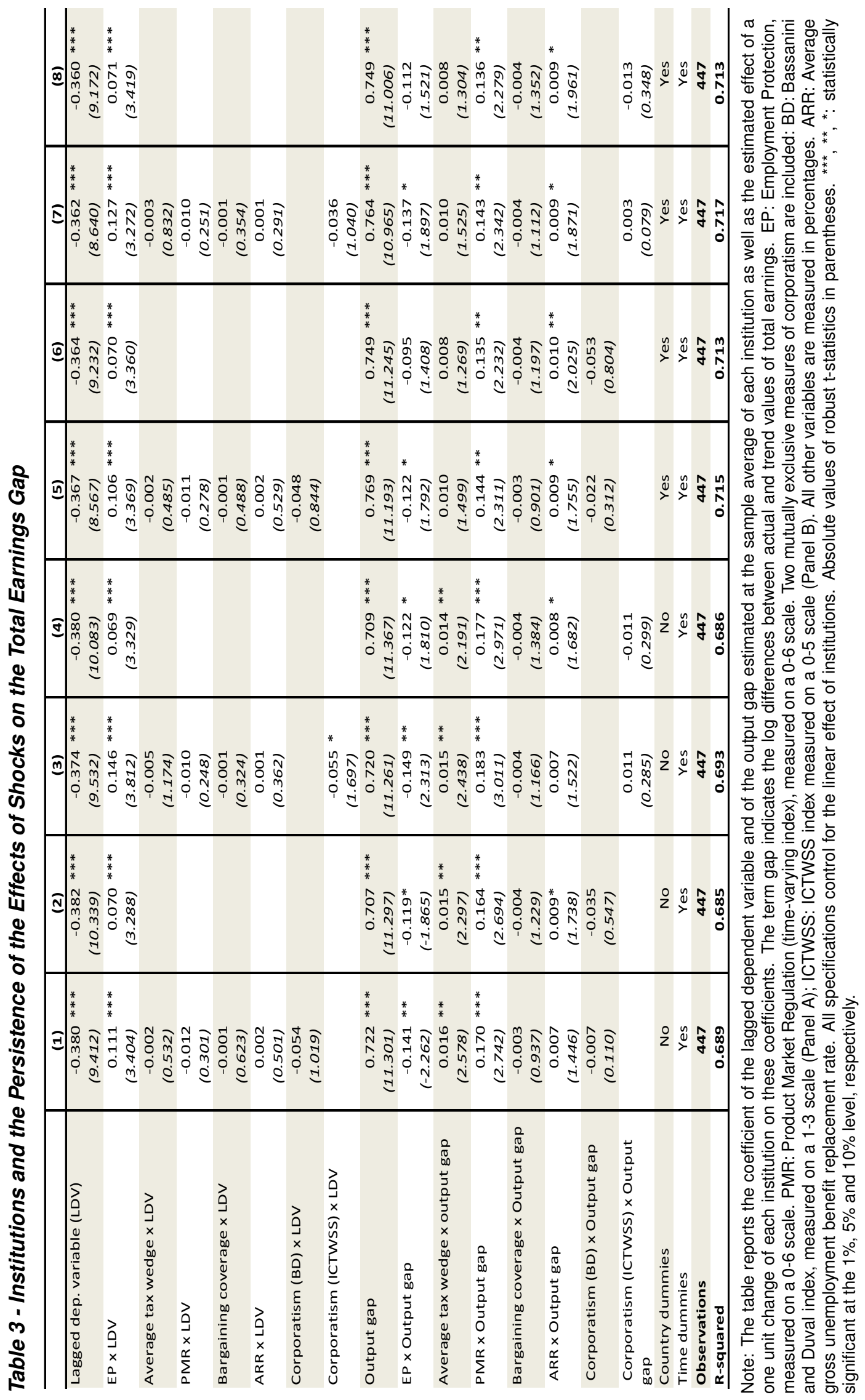


These results appear to be reasonably confirmed by the estimation of dynamic models allowing institutions to affect the degree of persistence in the labour market (cf. equation (9) above). Indeed, both the tax wedge and the replacement rate are significant at least at the $10 \%$ level in the preferred specification, that is excluding country fixed effect ${ }^{22}$ and insignificant interactions between institutions and the lagged dependent variable (columns 2 and 4 of Table 3). ${ }^{23}$ Yet, neither the tax wedge nor the replacement rate appears to have any effect on the persistence of macroeconomic shocks.

By contrast, employment protection (measured through the overall indicator of EP stringency) appears to increase the persistence of the effect of shocks on earnings while having a mitigating effect on their short-run impact. Indeed, there is a large theoretical literature suggesting that firms' optimal behaviour in the presence of positive firing costs is to compress both job creation and destruction at any stage of the business-cycle (see Bentolila and Bertola, 1990, Bertola, 1990 and Mortensen and Pissarides, 1999). To the extent that EP shelters insiders against the risk of job loss, they can also resist downward adjustment of wages after an adverse shock (Bertola and Rogerson, 1997, Bertola, 1999). However, aggregate estimates presented in Table 1 are inconclusive as regards whether the mitigating impact of EP is mainly due to a wage or an employment effect. In the next subsection, I will refine the identification strategy, which will allow us to get sharper conclusions on employment protection, even though only as regards dismissal regulations.

\subsection{Industry-Level Difference-in-Difference Analysis: Dismis- sal Regulation}

As pointed out in Section 1.2, in the case of dismissal rules for permanent workers (EPR hereafter), it is possible to improve upon the estimation strategy by following an industry-level difference-in-difference approach. The identification strategy is based on the assumption that the effect of EPR on the responsiveness of hours and wages to aggregate business-cycle shocks varies across industries and that these regulations are more likely to be binding in industries with a greater dismissal propensity (EP-binding industries). In order to reduce bias due to the possible relationship between EPR stringency and the cross-industry distribution of dismissals, I identify EPbinding industries based on dismissal rates by industry in the United States

\footnotetext{
${ }^{22}$ Note that similar estimates for the coefficient of the lagged dependent variable are obtained with or without the inclusion of country fixed effect. As suggested by Angrist and Pischke (2009), this is an indication that estimates obtained without including fixed effects are consistent and more efficient.

${ }^{23}$ Stringent anti-competitive product market regulation also appears to amplify the effect of shocks, according to dynamic models, but this is not detectable in static models. Therefore, no robust conclusion can be drawn from these estimates on the effect of these regulations on the transmission of shocks to the labour market.
} 
Table 4 - Effect of Dismissal Intensity on the Amplification/Mitigation of Shocks in the United States

\begin{tabular}{lc|c|c|c|c|c}
\hline & $\begin{array}{c}\text { Value added } \\
\text { (volume) }\end{array}$ & Total earnings & Hourly wages & Hours worked & $\begin{array}{c}\text { Dependent } \\
\text { employment }\end{array}$ & Dismissals \\
\hline output gap X avg. & $53.66^{* * *}$ & $30.56^{* * *}$ & 1.589 & $28.97^{* * *}$ & $29.98^{* * *}$ & $-22.77^{* *}$ \\
dismissal rate & $(4.654)$ & $(3.810)$ & $(0.382)$ & $(4.340)$ & $(4.588)$ & $(2.059)$ \\
Industry dummies & Yes & Yes & Yes & Yes & Yes & Yes \\
Time dummies & Yes & Yes & Yes & Yes & Yes & Yes \\
Observations & $\mathbf{4 6 2}$ & $\mathbf{4 6 2}$ & $\mathbf{4 6 2}$ & $\mathbf{4 6 2}$ & $\mathbf{4 6 2}$ & $\mathbf{1 4 3}$ \\
R-squared & $\mathbf{0 . 1 2 0}$ & $\mathbf{0 . 3 6 7}$ & $\mathbf{0 . 4 4 1}$ & $\mathbf{0 . 5 6 1}$ & $\mathbf{0 . 5 2 3}$ & $\mathbf{0 . 6 8 6}$ \\
\hline
\end{tabular}

Note: All dependent variable are gaps between the log of the actual and trend values of each variable. The average dismissal rate is expressed as the average of the ratio of dismissals to dependent employment for each available year (1996-2006, even years). Its global average is 0.0518 . Absolute value of robust t-statistics in parentheses. ${ }^{* * *},{ }^{* *}$ : statistically significant at the $1 \%$ and $5 \%$ level, respectively.

(i.e. the least regulated country).

This approach has become increasingly popular in the literature concerning the impact of EP on several performance variables (see e.g. Micco and Pages, 2006; Haltiwanger et al., 2008; Bassanini et al., 2009; Cingano et al., 2010; and Subramanian and Megginson, 2011). However, when the analysis focuses on the cyclical fluctuations induced by aggregate shocks, this intuitive identification strategy might be problematic. In fact, those industries that do not usually adjust through dismissals in normal times might disproportionately increase their dismissal rate during severe recessions, at least in the absence of regulations, so that the identification strategy might not be appropriate in bad times. For the identification strategy to be valid, one must assume that, in the absence of regulations, dismissals in EP-binding industries are no less anti-cyclical than in other industries. This assumption can be tested using industry data for the United States by estimating the following (difference-in-difference) specification:

$$
\log W G A P_{j t}=\beta B_{j} O G A P_{t}+\eta_{t}+\eta_{j}+\varepsilon_{i j t}
$$

where $\log W G A P$ is the industry-specific time-varying dependent variable, $O G A P$ is the aggregate output gap, $j$ and $t$ index industry and time, respectively, $B$ is the industry-level average of dismissal rates, $\eta$ s are fixed effects that capture all industry-specific time-invariant effects and aggregate timevarying factors, including nation-wide institutional reforms and the average effect of the output gap, and $\epsilon$ is an error term capturing idiosyncratic shocks that are unrelated to the business cycle. A positive sign of $\beta$ implies greater pro-cyclicality of high dismissal industries.

Results of this exercise are presented in Table 4. In the United States, dismissal-intensive industries appear to have more counter-cyclical dismissal rates and more pro-cyclical employment, total hours worked and real value added than non-binding industries. These findings suggest that the identification assumption spelled out above is unlikely to be weaker in bad times.

Panel A of Table 5 presents baseline results obtained by estimating the 
Table 5 - Industry-Level Total Earnings Fluctuations and Dismissal Regulations

\begin{tabular}{|c|c|c|c|c|c|c|}
\hline \multicolumn{7}{|c|}{ Panel A. Static models } \\
\hline & (1) & (2) & (3) & (4) & (5) & (6) \\
\hline Output gap & 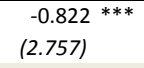 & & & & & \\
\hline Output gap x DR & $\begin{array}{l}34.833^{* * *} \\
(6.709)\end{array}$ & $\begin{array}{l}34.939 * * * \\
(7.310)\end{array}$ & $\begin{array}{l}35.869 * * * \\
(7.506)\end{array}$ & $\begin{array}{l}36.752 * * * \\
(7.436)\end{array}$ & $\begin{array}{l}38.662 * * * \\
(7.818)\end{array}$ & $\begin{array}{l}33.449 \text { *** } \\
(5.428)\end{array}$ \\
\hline EPR $\times$ DR $\times$ output gap & $\begin{array}{l}-5.343^{* *} \\
(2.400)\end{array}$ & $\begin{array}{l}-5.380 * * * \\
(2.654)\end{array}$ & $\begin{array}{l}-5.889 * * * \\
(3.075)\end{array}$ & $\begin{array}{l}-5.699 * * * \\
(2.738)\end{array}$ & $\begin{array}{l}-6.355 * * * \\
(3.250)\end{array}$ & $\begin{array}{l}-5.621 * * \\
(2.311)\end{array}$ \\
\hline Country dummies & Yes & No & No & No & No & No \\
\hline Industry dummies & Yes & Yes & No & No & No & No \\
\hline Country $x$ time dummies & No & Yes & Yes & Yes & Yes & Yes \\
\hline Industry $\mathrm{X}$ time dummies & No & No & Yes & No & Yes & Yes \\
\hline Country $\mathrm{x}$ industry dummies & No & No & No & Yes & Yes & No \\
\hline Observations & 8,604 & 8,604 & 8,604 & 8,604 & 8,604 & 8,582 \\
\hline R-squared & 0.229 & 0.406 & 0.478 & 0.417 & 0.488 & 0.336 \\
\hline \multicolumn{7}{|c|}{ Panel B. Dynamic models } \\
\hline & (1) & (2) & (3) & (4) & (5) & (6) \\
\hline Lagged dep. variable & $\begin{array}{l}-0.581^{* * *} \\
(16.787)^{2}\end{array}$ & $\begin{array}{l}-0.5677^{* * *} \\
(15.526)\end{array}$ & $\begin{array}{l}-0.596^{* * *} \\
(16.565)\end{array}$ & $\begin{array}{l}-0.578^{* * *} \\
(16.422)\end{array}$ & $\begin{array}{l}-0.5644^{* * *} \\
(15.080)\end{array}$ & $\begin{array}{l}-0.593^{* * *} \\
'(16.234)\end{array}$ \\
\hline Output gap x DR & $\begin{array}{l}23.439^{* * *} \\
(5.704)\end{array}$ & $\begin{array}{l}26.532 \text { *** } \\
(6.474)\end{array}$ & $\begin{array}{l}24.0611^{* * *} \\
(5.660)\end{array}$ & $\begin{array}{l}31.308^{* * *} \\
(5.411)\end{array}$ & $\begin{array}{l}30.168^{* * *} \\
(5.360)\end{array}$ & $\begin{array}{l}29.869 \text { *** } \\
(5.059)\end{array}$ \\
\hline EPR $\times$ DR $\times$ output gap & $\begin{array}{l}-3.529 * * \\
(2.208)\end{array}$ & $\begin{array}{l}-4.444^{* * *} \\
(2.677)\end{array}$ & $\begin{array}{l}-3.709^{* *} \\
(2.305)\end{array}$ & $\begin{array}{l}-5.249 * * \\
(2.179)\end{array}$ & $\begin{array}{l}-4.710 * \\
(1.932)\end{array}$ & $\begin{array}{l}-5.219^{* *} \\
'(2.175)\end{array}$ \\
\hline Lagged output gap x DR & & & & $\begin{array}{l}-10.005 * \\
(-1.688)\end{array}$ & $\begin{array}{r}-5.678 \\
(-0.960)\end{array}$ & $\begin{array}{r}-7.709 \\
(-1.271)\end{array}$ \\
\hline Lagged EPR $\times$ DR $\times$ output gap & & & & $\begin{array}{r}1.770 \\
(0.727)\end{array}$ & $\begin{array}{r}0.464 \\
(0.191)\end{array}$ & $\begin{array}{r}1.724 \\
(0.711)\end{array}$ \\
\hline Country dummies & No & No & No & No & No & No \\
\hline Industry dummies & No & No & No & No & No & No \\
\hline Country $x$ time dummies & Yes & Yes & Yes & Yes & Yes & Yes \\
\hline Industry $\mathrm{X}$ time dummies & Yes & No & Yes & Yes & No & Yes \\
\hline Country $\mathrm{x}$ industry dummies & No & Yes & Yes & No & Yes & Yes \\
\hline Long-term coeff. of EPR x output gap & -6.074 & -7.831 & -6.227 & -6.023 & -7.528 & -5.891 \\
\hline long-term EPRB coeff.: p-value & 0.0264 & 0.00768 & 0.0204 & 0.0432 & 0.0171 & 0.0439 \\
\hline Observations & 8,582 & 8,582 & 8,582 & 8,582 & 8,582 & 8,582 \\
\hline R-squared & 0.540 & 0.513 & 0.563 & 0.541 & 0.513 & 0.563 \\
\hline
\end{tabular}

Note: The dependent variable is the industry-specific gap between the logs of actual and trend total earnings. DR: average US Dismissal rate, by industry (average $=0.0518$ ). EPR: employment protection for regular contracts. Other interactions required for identification are included. All variables are in levels except in Column 6 of Panel A where they are in first-differences. Absolute values of robust t-statistics in parentheses. ${ }^{* * *}$, ${ }^{* *}$, ${ }^{*}$ : statistically significant at the $1 \%, 5 \%$ and $10 \%$ level, respectively.

simplest static difference-in-difference model corresponding to equation (8). Column 1 includes only country and industry dummies and, for identification purposes, controls for the direct effect of the output gap and EPR (not shown in the table because its coefficient might be biased due to omitted institutional controls). This specification provides a useful benchmark to check that the inclusion of time dummies, by sweeping away common cyclical components, does not alter our estimates of the amplification/mitigation effect of dismissal regulations. The disadvantage of this specification is, obviously, that it is potentially affected by omitted variable biases. By contrast, in all subsequent columns, specifications include country-by-time dummies, thereby controlling for all aggregate effects, including the direct effect of the output gap and EPR. The specification corresponding to Column 2 controls only for aggregate country-specific time-varying factors but not for industry-specific trends or for time-invariant heterogeneity across countries and industries, which is done in Columns 3-5. Column 6 replicates the ex- 
ercise reported in Column 5 in first differences, thereby looking at the effect of EPR on the elasticities of changes in log industry earnings to changes in the aggregate output gap. Results are remarkably consistent across specifications and confirm the shock-mitigating short-run impact of EP. Taken at face value, a one-point increase in EPR (approximately corresponding to half of the distance between the United States and the OECD average) would imply a reduction of between $15 \%$ and $17 \%$ in the elasticity of total earnings to the output gap. ${ }^{24}$

These results are broadly confirmed by dynamic specifications reported in Panel B of Table 5, which allow for persistence. ${ }^{25}$ In particular, two remarks are in order: i) the percentage impact of EPR on the elasticity of industry-level earnings fluctuations to the aggregate gap is close to that estimated through static models; and ii) the long-run impact of EPR on this elasticity - that is the effect that would be realized if the shocks were permanent rather than transitory - is somewhat larger than what is obtained in static models but the difference does not appear significant. Interestingly, the coefficient of the lagged dependent variable is very precisely estimated and shows no variation across models, which suggests that omitting countryby-industry fixed effects is preferable (see Angrist and Pischke, 2009). This does not appear surprising insofar as these fixed effects are in general insignificantly different from zero. Indeed, if this were not the case, this would imply that certain countries/years have a gap persistently greater or smaller than zero, which is ruled out by the fact that gaps are obtained through HP filtering.

Insofar as employment protection does not vary much over-time, crosscountry variation is key to identify the effect. We might therefore worry that specific countries might drive the results. I therefore drop countries one by one and re-estimate my specifications. Figure 1 reports results for my preferred specification (Column 3 of Panel A). It appears that no significant differences emerge as regards the coefficient of the interaction between EPR, the output gap and the US dismissal rate.

I argued that one of the key advantages of our difference-in-differences approach is that it allows us to control for other aggregate confounding factors, including other institutions and policies, some of which are not easy to quantify. This claim is correct provided that there is no reason to believe that

\footnotetext{
${ }^{24}$ Remember that, as discussed in Section 2.2, one can obtain the estimated percentage impact on the elasticity by multiplying by 100 the ratio between the third and the second row of Panel A of Table 5.

${ }^{25}$ In addition, Columns 4 to 6 also allow for a one-period lagged impact of aggregate shocks, which is assumed to vary as a function of layoff-intensity and EPR. This is important given that the evidence suggests that the measured elasticity of total earnings to aggregate shocks is greater if shocks are allowed to have a delayed impact on the labour market. In these models persistence is assumed to be the same across countries and industries, except for the one-period lagged effect of the shock. See below for a more general treatment of the possible effect of EPR on persistence.
} 


\section{Figure 1 - Sensitivity Analysis of the Mitigation Effect of EPR When Countries Are Excluded One-by-One from the Sample}

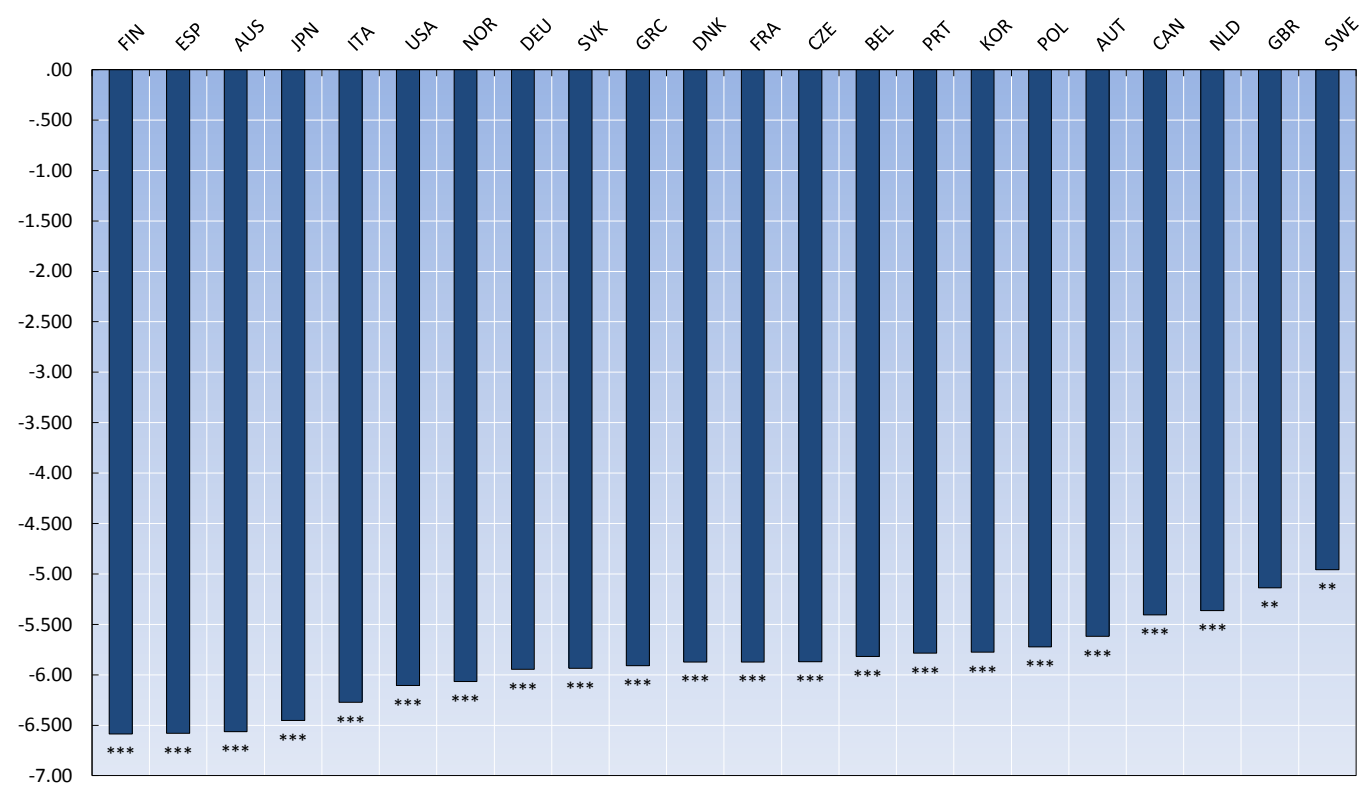

Note: The figure refers to the specification reported in Columns 3 of Panel A of Table 5. Coefficient estimates refer to the interaction between EPR, the output gap and US dismissal rates and are obtained by excluding indicated countries one-by-one. ${ }^{* \star *},{ }^{* \star}$ : statistically significant at the $1 \%$, and $5 \%$ level, respectively.

the impact of aggregate institutions on earnings and employment fluctuations varies, on average, between EP-binding and other industries and/or proportionally to the industry layoff propensity. For institutions that have no direct bearing on layoffs, it is difficult to think of convincing reasons for such a differential impact. Yet, can we provide stronger evidence that this is the case? In order to do so, I augment my preferred specification with interactions between our quantitative indicator of layoff propensity and the aggregate indicators of labour market institutions and product market regulations, which are typically used in aggregate unemployment equations and which we already considered in Section 4.1.26 Table 6 shows that our estimates are sensitive to the simultaneous inclusion of all these institutions interacted with dismissal rates (Column 1 and 2). However, sequential elimination of the least significant co-variates leads to a specification in which only EPR is significant, suggesting that the insignificance of this variable in the first columns is mainly due to a multicollinearity problem. ${ }^{27}$

Countries that have stringent dismissal regulations typically have rigid legislation for hiring on temporary contracts. Therefore, one can ask whether

\footnotetext{
${ }^{26}$ Insofar as these controls are only used to check that the estimate of the relevant coefficient for EPR are not due to confounding factors, and EPR and product market regulation (PMR) are especially correlated in cross-section, I prefer to include here the aggregate PMR indicator for 1998, which is based on all industries and aspects of anti-competitive regulation.

${ }^{27}$ It is also reassuring that none of these covariates turn out significant if included in the specification without including EPR (results available from the author upon request).
} 
the estimated effect of EPR in Table 5 is not in fact due to regulation for temporary contracts. In order to check for this, I include the index of employment protection concerning regulations for temporary contracts (EPT) interacted with the output gap and US dismissal rates in Column 7 of Table 6. The estimated effect turns out to be even greater for EPR, thereby confirming our previous results ${ }^{28}$

Short-time work schemes, which played a key role in mitigating the labour market effects of the 2008/09 recession, are typically more intensively used in countries with stringent EP (see Hijzen and Venn, 2010). Unfortunately, cross-country comparable data on these schemes for most OECD countries are available only since 2007 . In order to check that observed mitigation effects of EPR are not due to these schemes, I perform two alternative sensitivity exercises. Insofar as many countries that did not have such schemes introduced them only after the onset of the 2008/09 crisis, I include a dummy for existence of a scheme in 2007 (interacted with output gap and US dismissal rates), which is a noisy indicator of the existence of short-time work schemes during the whole period of analysis. The disadvantage of this indicator is that it does not take into account that take-up rates differ markedly across schemes and over time (see Hijzen and Venn, 2010). As an alternative exercise, I therefore exclude all countries that had already implemented a short-time work scheme by 2007. In both cases, estimates of the mitigating effect of EPR appear robust (Table 6, Columns 8 and 9), suggesting that the omission of an adequate control for such short-time work schemes does not impair the reliability of results presented in Table 5.

Finally, there is evidence that, in countries with restrictive dismissal regulations, firms with a larger share of permanent workers and/or a greater share of blue-collar and low-skilled white-collar workers tend to have more rigid wage-setting schemes (Babecký et al. 2009, 2010).

\footnotetext{
${ }^{28}$ Care is however required in interpreting these results, insofar as the EPT indicator does not capture cross-country differences in enforcement of regulations. In fact, EP is typically enforced by individuals who consider themselves as victims and lodge a complaint with the competent tribunals or courts. In the case of dismissals, potential plaintiffs are easily identified and able to react, whereas victims of breaches of rules on temporary contracts (particularly in the case of violations of hiring restrictions under such contract) are much less likely to make a complaint. As a consequence, enforcement problems are particularly important in the case of EPT (see Bassanini et al., 2010, for an extensive discussion). For this reason, in another specification, I also include the trend aggregate share of temporary workers as a substitute for EPT, which arguably captures all determinants of temporary contracts. Results for EPR remain broadly unchanged (available from the author upon request).
} 


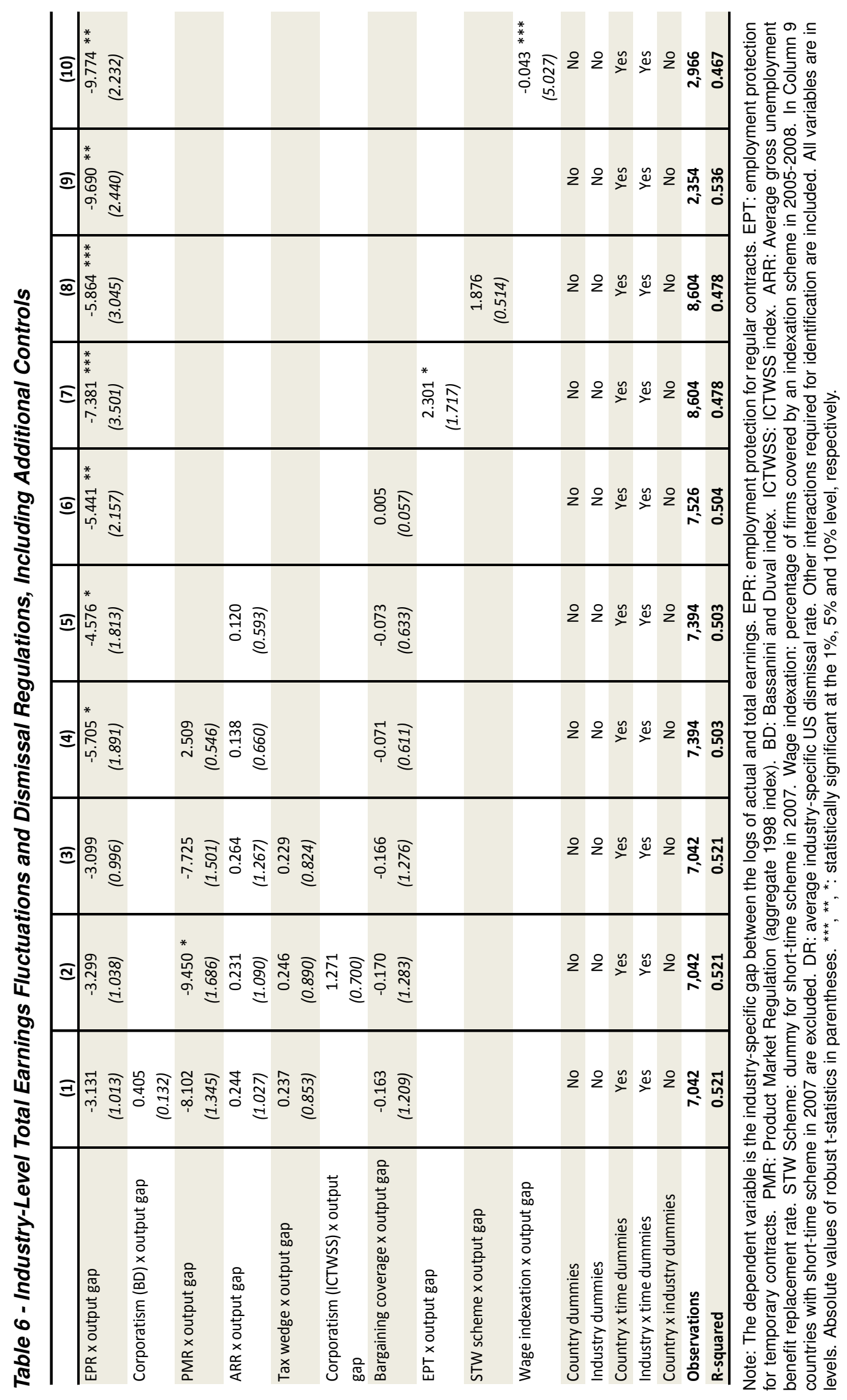


In order to check that our results are not due to the correlation between EPR and wage-rigidity, I include the percentage of firms covered by a wage indexation scheme in 2005-2008 (the only period for which data are available) interacted with US dismissal rates and the output gap. ${ }^{29}$ Reassuringly, the inclusion of this additional control does not reduce the estimated effect of EPR (Table 6, Column 10).

Is the mitigation effect of dismissal restrictions on the transmission of output shocks due to mitigation of employment or hourly wage fluctuations? Table 7 looks at this issue in detail by estimating separate equations for average hourly wages, total hours worked and employee headcounts. While no significant effect emerge as regards hourly wages, a strong impact is estimated for employee headcounts, with a one unit increase in the EPR indicator from the OECD average leading to about a 35\% reduction in the elasticity of employment headcounts to aggregate output shocks. Interestingly, the effect on total hours fluctuations is insignificantly different and even slightly smaller, suggesting that all the effect of EPR is concentrated in retaining workers into their jobs during downturns, consistent with theoretical priors.

Up to this point, I have implicitly assumed that policies and institutions do not affect the magnitude of the fluctuations of aggregate output. In general, this requires some caution in interpreting the quantitative estimates presented so far, because a policy could have opposite effects on output and the labour market transmission of output fluctuations. From a qualitative point of view, the impact of EP on the output gap can be examined using the same methodology as above. If EP does have a mitigating impact on the output gap, one would expect this impact to be greater in EP-binding industries (see also Section 2.2). Evidence presented in Table 8 suggests that in countries with stringent EP, an aggregate GDP swing would translate in smaller differences in value-added fluctuations between EP-binding and other industries. In other words, EP for regular contracts appears to have a mitigation effect both on output and on the transmission of output fluctuations to the labour market. Overall, this suggests that we can consider the shock-mitigation effect of EP for regular contracts derived from Table 5 as providing a lower-bound estimate of the true effect.

As already discussed, an adverse shock might not only compress earnings and reduce employment. Its effects might also persist over time, and

${ }^{29}$ Data on wage indexation were collected the Eurosystem's Wage Dynamics Network (WDN) coordinated by the European Central Bank (ECB), which administered in 2007 and 2008 a firm-level survey including, inter alia, questions concerning wage-adjustment procedures in use in the firm with reference to the last years before the survey (see Druant et al., 2009, and Babecký et al., 2009, for more details). The ECB and the WDN network kindly made available these data at the level of country-by-industry cells (with the business sector being disaggregated into 5 industries). The analysis made here assumes that the frequency of each policy in the survey period is representative of the true frequency in the past 20 years. 
Table 7 - Industry-Level Wage and Employment Fluctuations and Dismissal Regulations

\begin{tabular}{|c|c|c|c|c|}
\hline \multicolumn{5}{|c|}{ Panel A. Hourly wage } \\
\hline & (1) & (2) & (3) & (4) \\
\hline Output gap x DR & $\begin{array}{r}-0.219 \\
(0.182)\end{array}$ & $\begin{array}{r}-0.092 \\
(0.061)\end{array}$ & $\begin{array}{r}-0.439 \\
(0.358)\end{array}$ & $\begin{array}{r}-0.807 \\
(0.519)\end{array}$ \\
\hline EPR $\times$ DR $\times$ output gap & $\begin{array}{r}1.698 \\
(1.128)\end{array}$ & $\begin{array}{r}1.175 \\
(0.760)\end{array}$ & $\begin{array}{r}1.693 \\
(1.112)\end{array}$ & $\begin{array}{r}1.188 \\
(0.752)\end{array}$ \\
\hline Country dummies & No & No & No & No \\
\hline Industry dummies & Yes & No & No & No \\
\hline Country $x$ time dummies & Yes & Yes & Yes & Yes \\
\hline Industry $x$ time dummies & No & Yes & No & Yes \\
\hline Country $\mathrm{x}$ industry dummies & No & No & Yes & Yes \\
\hline Observations & 8,582 & 8,582 & 8,582 & 8,582 \\
\hline R-squared & 0.212 & 0.262 & 0.227 & 0.276 \\
\hline \multicolumn{5}{|c|}{ Panel B. Hours worked } \\
\hline & (1) & (2) & (3) & (4) \\
\hline Output gap x DR & $\begin{array}{l}23.869^{* * *} \\
(16.003)\end{array}$ & $\begin{array}{l}23.562 * * * \\
(13.051)\end{array}$ & $\begin{array}{l}25.202 \text { *** } \\
(16.102)\end{array}$ & $\begin{array}{l}26.031 \text { *** } \\
(14.317)\end{array}$ \\
\hline$E P R \times D R \times$ output gap & $\begin{array}{l}-7.113^{* * *} \\
(3.604)\end{array}$ & $\begin{array}{l}-7.061 * * * \\
(3.627)\end{array}$ & $\begin{array}{l}-7.416^{* * *} \\
(3.680)\end{array}$ & $\begin{array}{l}-7.520 * * * \\
(3.826)\end{array}$ \\
\hline Country dummies & No & No & No & No \\
\hline Industry dummies & Yes & No & No & No \\
\hline Country $x$ time dummies & Yes & Yes & Yes & Yes \\
\hline Industry $\mathrm{x}$ time dummies & No & Yes & No & Yes \\
\hline Country $\mathrm{x}$ industry dummies & No & No & Yes & Yes \\
\hline Observations & 8,582 & 8,582 & 8,582 & 8,582 \\
\hline R-squared & 0.380 & 0.444 & 0.391 & 0.457 \\
\hline \multicolumn{5}{|c|}{ Panel C. Employee headcount } \\
\hline & (1) & (2) & (3) & (4) \\
\hline Output gap x DR & $\begin{array}{l}21.3611^{* * * *} \\
(14.030)\end{array}$ & $\begin{array}{l}21.0177^{* * *} \\
(10.736)\end{array}$ & $\begin{array}{r}22.226 \text { *** } \\
(13.735)\end{array}$ & $\begin{array}{l}22.669 \text { *** } \\
(10.956)\end{array}$ \\
\hline$E P R \times D R \times$ output gap & $\begin{array}{l}-6.940 * * * \\
(3.696)\end{array}$ & $\begin{array}{l}-7.430 * * * \\
(3.977)\end{array}$ & $\begin{array}{l}-7.157^{* * *} \\
(3.726)\end{array}$ & $\begin{array}{l}-7.728 * * * \\
(4.092)\end{array}$ \\
\hline Country dummies & No & No & No & No \\
\hline Industry dummies & Yes & No & No & No \\
\hline Country $\mathrm{x}$ time dummies & Yes & Yes & Yes & Yes \\
\hline Industry $\mathrm{x}$ time dummies & No & Yes & No & Yes \\
\hline Country $\mathrm{x}$ industry dummies & No & No & Yes & Yes \\
\hline Observations & 8,604 & 8,604 & 8,604 & 8,604 \\
\hline R-squared & 0.346 & 0.410 & 0.362 & 0.425 \\
\hline
\end{tabular}

Note: The dependent variables are industry-specific gaps between logs of actual and trend values. EPR: employment protection for regular contracts. DR: average industry-specific US dismissal rate. Other interactions required for identification are included. All variables are in levels. Absolute values of robust t-statistics in parentheses. ${ }^{\star \star *}$ : statistically significant at the $1 \%$ level.

the degree of persistence is likely to be affected by policies and institutions. Aggregate dynamic models presented in Table 3 above, where the speed of shock re-absorption is assumed to depend on policies and institutions, suggest that EP significantly affects the persistence of shocks. The impact of EP for regular contracts on persistence is confirmed by industry-level analysis, using again a difference-in-difference approach (see Section 2.2). Indeed, 
Table 8 - Industry-Level Real Value Added Fluctuations and Dismissal Regulations

\begin{tabular}{l|c|c|c|c}
\hline & $\mathbf{( 1 )}$ & $\mathbf{( 2 )}$ & $\mathbf{( 3 )}$ & $\mathbf{( 4 )}$ \\
\hline Output gap x DR & $26.326^{* * *}$ & $24.059^{* * *}$ & $27.977^{* * *}$ & $26.704^{* * *}$ \\
& $(11.966)$ & $(8.839)$ & $(12.054)$ & $(9.220)$ \\
EPR x DR x output gap & $-8.127^{* * *}$ & $-8.395^{* * *}$ & $-8.272^{* * *}$ & $-8.779^{* * *}$ \\
& $(3.481)$ & $(3.774)$ & $(3.427)$ & $(3.834)$ \\
Country dummies & No & No & No & No \\
Industry dummies & Yes & No & No & No \\
Country x time dummies & Yes & Yes & Yes & Yes \\
Industry x time dummies & No & Yes & No & Yes \\
Country x industry dummies & No & No & Yes & Yes \\
Observations & $\mathbf{8 , 1 9 4}$ & $\mathbf{8 , 1 9 4}$ & $\mathbf{8 , 1 9 4}$ & $\mathbf{8 , 1 9 4}$ \\
R-squared & $\mathbf{0 . 1 5}$ & $\mathbf{0 . 2 3 9}$ & $\mathbf{0 . 1 6 3}$ & $\mathbf{0 . 2 5 3}$ \\
\hline
\end{tabular}

Note: The dependent variable is the industry-specific gap between the logs of actual and trend value added (in volume terms). EPR: employment protection for regular contracts. DR: average industry-specific US dismissal rates. Other interactions required for identification are included. All variables are in levels. Absolute values of robust t-statistics in parentheses. ${ }^{* * *}$ : statistically significant at the $1 \%$ level.

Table 9 shows that more stringent dismissal regulation is associated with greater persistence of total earnings in industries where US dismissal rates are greater. Taken at face value, these estimates imply that the half-life of the effect of a temporary macroeconomic shock on total earnings would be $13 \%$ smaller in a country where the EPR indicator is one unit below the OECD average, than in an average OECD country. ${ }^{30}$ Moreover, firing restrictions delay the re-absorption of the initial effect of shocks on total earnings mainly through their effect on the speed of adjustment of wages, while no significant effect is found on hours or employment. Indeed, Table 10 shows that more stringent dismissal regulation is associated with greater persistence of average wages in industries where US dismissal rates are greater, while I find no significant cross-industry difference for employment and hours. This finding suggests that stringent dismissal regulations could be among the factors behind the slow reaction of wages to shocks. Indeed, as discussed above, economic theory and the available empirical evidence support the conclusion that wage rigidity is likely to be more widespread when firing restrictions are high, since strong insiders can more easily resist real wage cuts.

Finally, there is also no evidence of differences in the persistence of valueadded deviations from their respective trends between EP-binding and other industries (see Table 10). This cautiously suggests that EP for regular contracts has no consequence in terms of the speed of re-absorption of the impact of macroeconomic shocks on GDP (and therefore the output gap). As a consequence, estimated impacts reported above need not be compounded with an additional effect on GDP persistence.

30 These estimates also appear robust to changes in model specifications, in particular to the inclusion of additional institutional controls, and to excluding countries one-by-one from the sample (results available from the author upon request). 


\begin{tabular}{|c|c|c|c|c|c|c|c|c|c|c|c|c|}
\hline - & 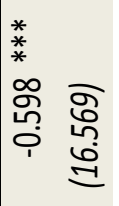 & 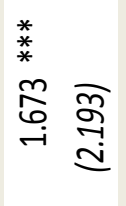 & 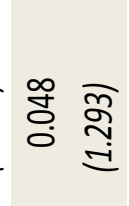 & 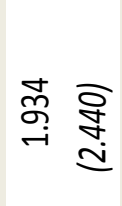 & 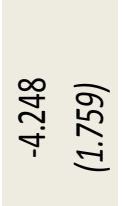 & 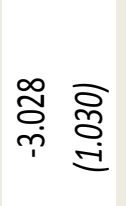 & 2 & $\stackrel{\check{\Perp}}{\rightleftharpoons}$ & 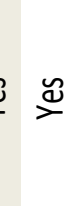 & జ & $\begin{array}{l}\text { : } \\
\text { นุ̊ }\end{array}$ & 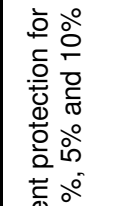 \\
\hline$\Xi$ & 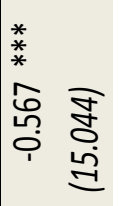 & 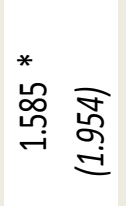 & ס્ठ & 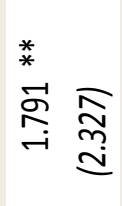 & 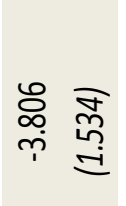 & 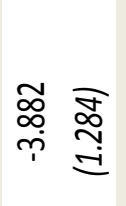 & 운. & $\stackrel{\varpi}{\check{2}}$ & $\stackrel{\Perp}{\nu}$ & 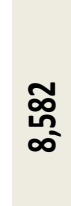 & ำ & 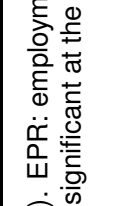 \\
\hline $\bar{\Xi}$ & 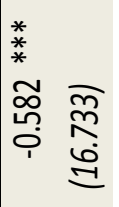 & 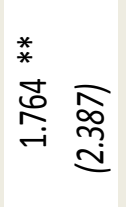 & 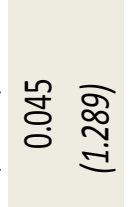 & 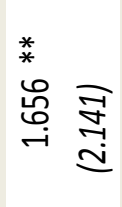 & 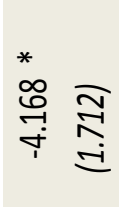 & 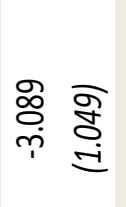 & 웅. & $\stackrel{\Perp}{\rightleftharpoons}$ & $2 \frac{2}{2}$ & 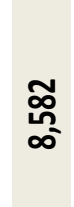 & 落 & 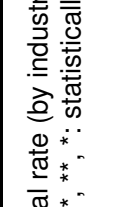 \\
\hline 뜨 & 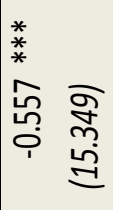 & 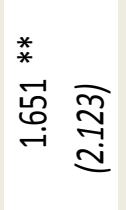 & 灾 & 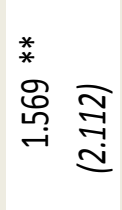 & 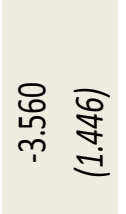 & 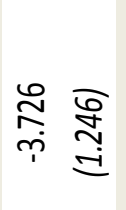 & $\stackrel{\breve{\Perp}}{\rightleftharpoons}$ & $\stackrel{\varpi}{\rightleftharpoons}$ & 2 & 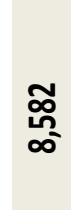 & 吉 & 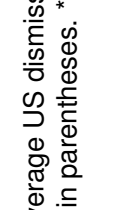 \\
\hline$\Xi$ & 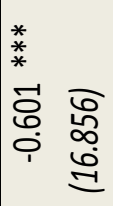 & 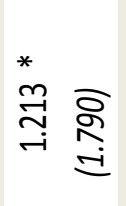 & 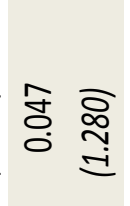 & 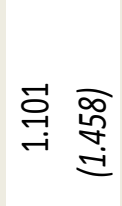 & 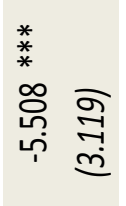 & & 울 & 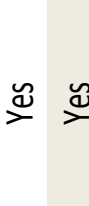 & $\stackrel{\check{\mu}}{2}$ & 怘 & 葅 & 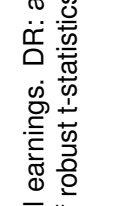 \\
\hline$\overline{\boldsymbol{m}}$ & 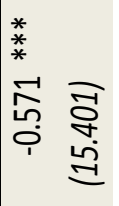 & ָㅠㅇ శ్ర్ర & 怘 & 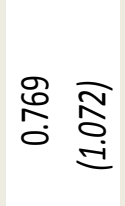 & 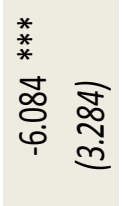 & & 인 & $\stackrel{\dddot{\Perp}}{\stackrel{0}{2}}$ & $\stackrel{\varrho}{\rightleftharpoons}$ & $\begin{array}{c}\widetilde{\infty} \\
\infty \\
\infty\end{array}$ & 孚 & 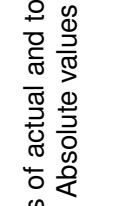 \\
\hline$\approx$ & 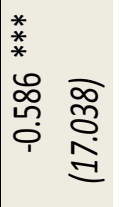 & 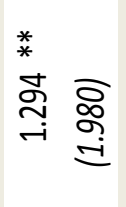 & 守 $\underset{0}{\stackrel{\Xi}{\approx}}$ & 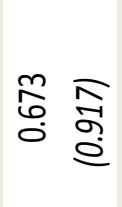 & 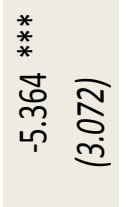 & & 일 & 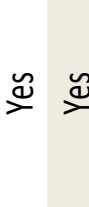 & $\hat{2} \stackrel{0}{2}$ & 怘 & 芯 & 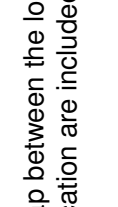 \\
\hline$\Xi$ & 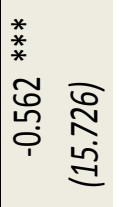 & $\stackrel{*}{\stackrel{*}{\rightarrow} \underset{i}{\stackrel{g}{\sigma}}}$ & $\begin{array}{ll}\stackrel{0}{0} \\
\stackrel{0}{0}\end{array}$ & 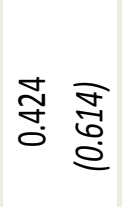 & 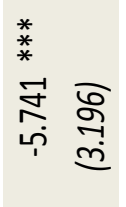 & & $\stackrel{\mathscr{\Perp}}{\varnothing}$ & $\stackrel{\varpi}{\stackrel{2}{亠}}$ & 2 & $\begin{array}{l}\text { ని } \\
\text { ధ్ } \\
\infty\end{array}$ & ণ্ & 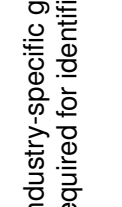 \\
\hline & 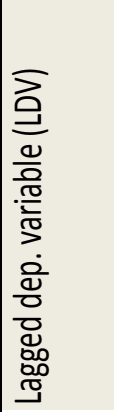 & 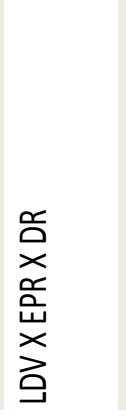 & 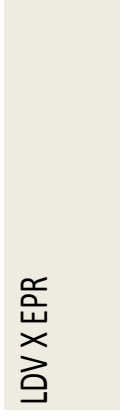 & $\begin{array}{l}\text { 嗠 } \\
\text { × } \\
\text { 总 }\end{array}$ & 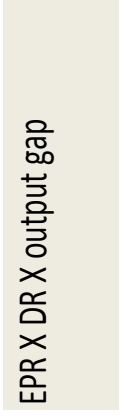 & 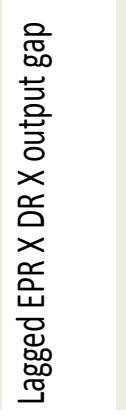 & 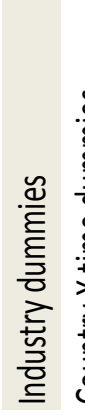 & 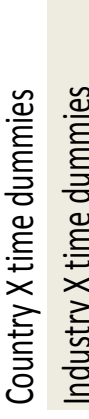 & 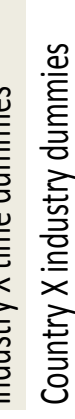 & 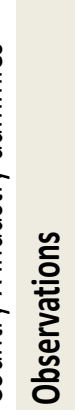 & 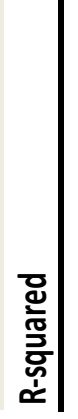 & 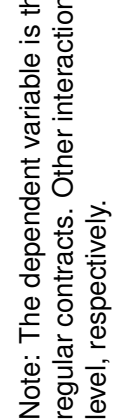 \\
\hline
\end{tabular}




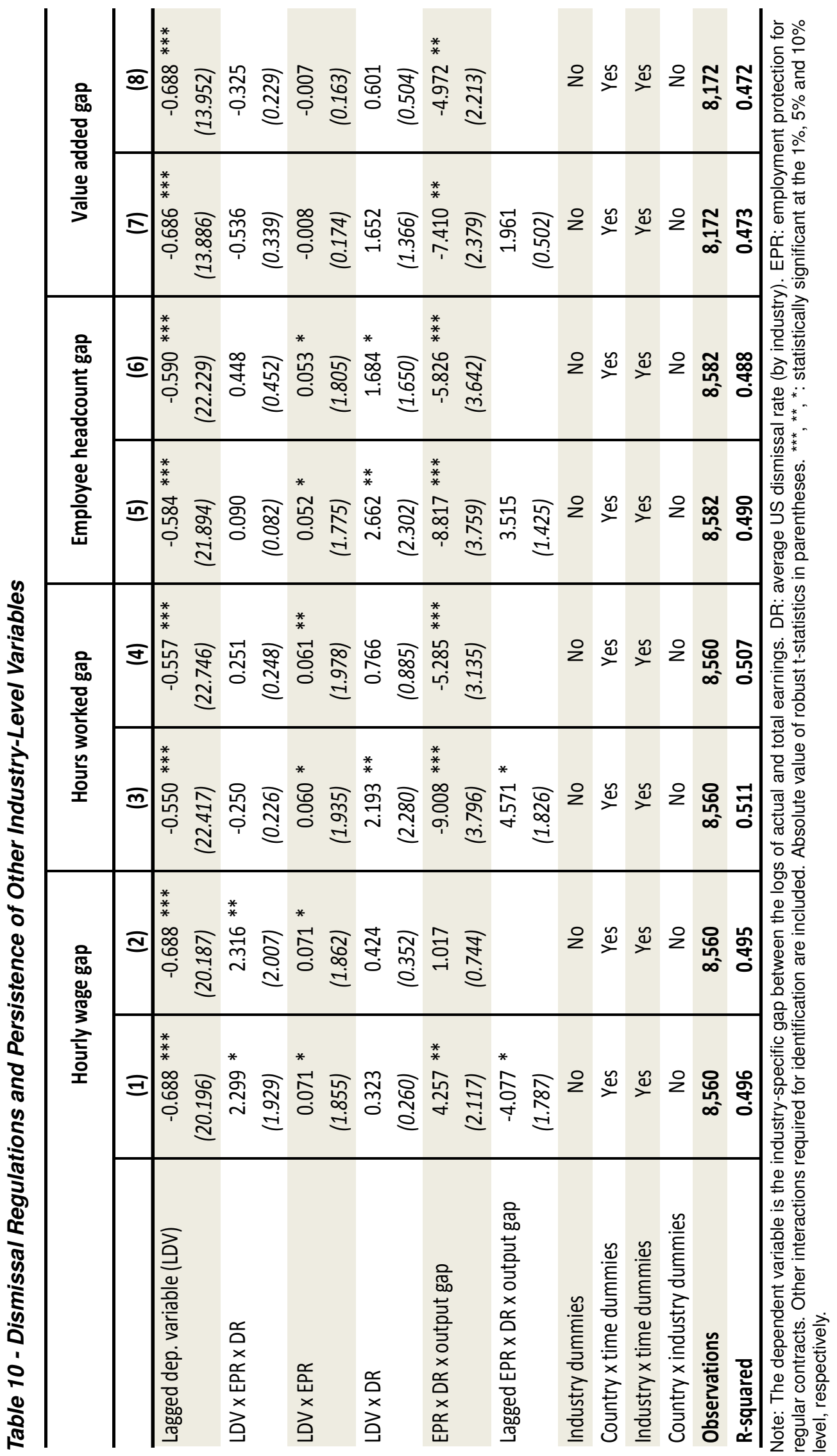


What do the counteracting effects of firing restrictions on shock amplification and persistence imply for labour-income smoothing? Subject to reasonable assumptions (see Section 2.2), it is possible to derive, from the econometric estimates presented above, the effect of EP on the cumulated impact of an adverse temporary shock on total earnings, measured under different assumptions about the discount rate (Figure 2). These estimates suggest that, in a country where the indicator of stringency of EP for regular contracts is one unit below the OECD average - i.e., approximately the level of the United Kingdom, the actual value of the total cumulated loss of labour income due to a one-time adverse macroeconomic shock would be about $27 \%$ larger than in the average OECD country. This effect would result from the combination of larger employment fluctuations partially compensated by a more rapid adjustment of hourly wages to the equilibrium.

\section{Figure 2 - Percentage Effect of Dismissal Regulations on the Total Cumulated Loss of Labour Income Due to an Adverse Shock}

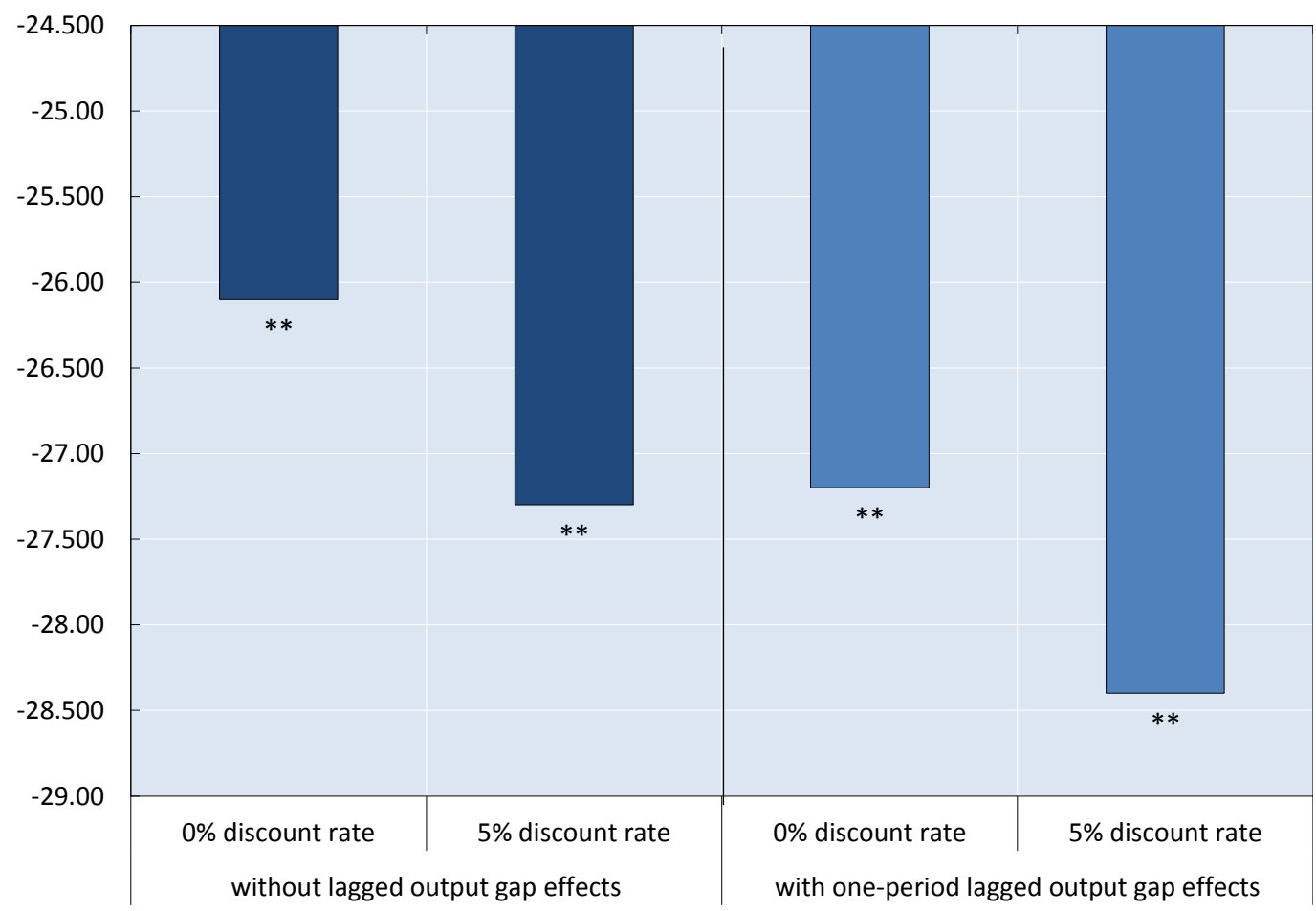

Note: Estimated percentage effect of a one unit EPR shift from the OECD average on the actual value of the total cumulated loss (gain) in labour income due to a one-shot adverse (favourable) macroeconomic shock. Effects are computed assuming linear utility and a discount rate of, alternatively, $0 \%$ and $5 \%$. Without lagged effects means that the direct effect of the output gap is assumed to be only contemporaneous. ${ }^{* *}$ : statistically significant at the $5 \%$ level, respectively.

The analysis of the impact of institutions presented so far has considered average effects on earnings, hours worked, employment and wages. However, these averages can hide large asymmetries in adjustment patterns, particularly in the case of employment fluctuations. For this reason, in the web appendix, I examine the effect of institutions on fluctuations of the earnings 
distribution. The main result of this extension is that stringent dismissal regulations also appear to reduce the counter-cyclicality of the earnings dispersion between high and low-educated labour.

\subsection{Industry-Level Difference-in-Difference Analysis: Statu- tory Minimum Wages}

By preventing downward adjustment at the bottom of the distribution, minimum wages can be expected to significantly affect wage adjustments in the aftermath of an adverse aggregate shock. Whether the lack of wage adjustment will be reflected in stronger adjustments in employment or along other margins remain an open question. I have not considered the minimum wage so far because comparable time-series are available for only the subset of countries where minimum wages are imposed by law or regulation, rather than being set by collective bargaining among social partners. ${ }^{31}$ In this section, I analyse the effects of the minimum wage in these countries through an industry-level difference-in-difference approach similar to that implemented in the case of EP. The identifying assumption is that changes in minimum wages have a greater impact on wage and earnings cyclicality in industries that are more heavily reliant on low-wage labour. In order to reduce bias due to the possible relationship between minimum wages and the distribution of low-wage employment, low-wage industries are identified based on the incidence of low-wage workers by industry in one specific country, the United Kingdom, prior to the introduction of statutory minimum wages in that country in 1999.32

I measure minimum wages as the economy-wide ratio of the gross statutory minimum wage to the median wage. This ratio, however, could be endogenous, due to the cyclical fluctuations of median wages. Therefore, I estimate baseline specifications using both OLS and instrumental variables (IV) approaches, using the logarithm of the real minimum wage in 2000 US dollars purchasing power parities interacted with the output gap as an instrument for the ratio of the minimum wage to median earnings interacted with the output gap.

\footnotetext{
31 These include Australia, Belgium, Canada, Czech republic, France, Greece, Japan, Korea, the Netherlands, Poland, Portugal, Slovak republic, Spain, the United Kingdom and the United States.

${ }^{32}$ In practice, it is assumed that the greater the fraction of low-paid workers in the United Kingdom between 1994 and 1998, the larger the extent to which the minimum wage is binding. In sensitivity analyses, I alternatively classify minimum-wage-binding industries using the share of those without any diploma and the share of those with low educational attainment. Results presented in this section are robust to changes in the benchmark used to classify industries.
} 


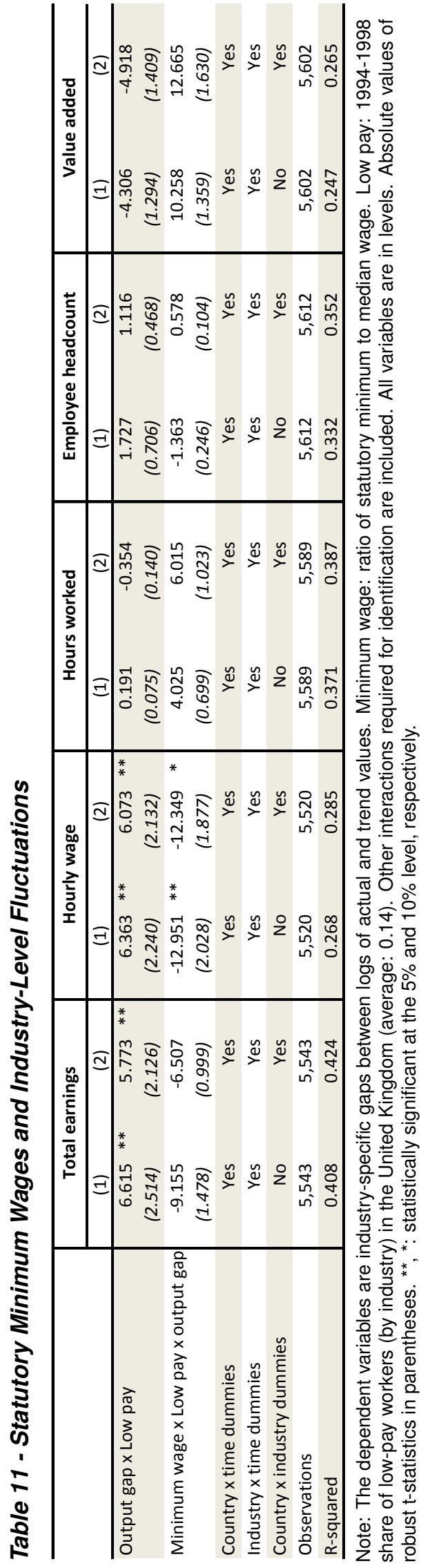


However, exogeneity tests ${ }^{33}$ could never reject the hypothesis that the interaction between the output gap and the ratio of the minimum wage to median earnings is exogenous, which suggests that OLS estimates are consistent and more efficient. Thus, in the following, I will discuss only results based on OLS.

Difference-in-difference estimates suggest that minimum wages mitigate the impact of macroeconomic shocks on the cyclicality of hourly wages (Table 11). A ten percentage point increase in the ratio of minimum to median wages from the OECD average appears to reduce the elasticity of hourly wages to the output gap by 0.18 in the average industry (whose share of low-pay workers is about 0.14 ). This is a noteworthy effect from an economic point of view, taken into account the relatively low elasticity of wage fluctuations (see for example Table 1, above) ${ }^{34}$ However, possibly due to the heterogeneous impact of the minimum wage on the cyclicality of employment and hours worked, I find no significant impact on the transmission of GDP shocks onto total earnings. I also cannot find any effect of minimum wages on real value added fluctuations. ${ }^{35}$

\section{Concluding Remarks}

This paper has investigated the role of labour market institutions in propagating macroeconomic shocks to the labour market and explaining earnings fluctuations at the aggregate levels. There is some evidence that generous unemployment benefits and progressive labour taxes amplify the effect of macroeconomic shocks on labour income. This suggests that, even if the tax and transfer system mitigates the transmission of individual earnings volatility onto household disposable income (see e.g. OECD, 2011), providing adequate income security is more difficult in a recession. By amplifying the effects of shocks on gross labour income, and therefore government revenues, these measures can be extremely costly for the government budget, underlying the importance for countries to achieve a sound fiscal stance during periods of growth, so as to have the fiscal capacity to sustain income support for workers during a crisis.

By contrast, policies that keep workers in their current jobs, such as employment protection for regular workers, are likely to mitigate the loss of labour income in downturns. The reduction in the risk of job and earnings losses associated with stricter dismissal regulations appears to be particularly large for workers at the bottom of the earnings distribution. However,

\footnotetext{
${ }^{33}$ Available from the author upon request.

${ }^{34}$ These results are also robust to exclusion of countries one-by-one from the sample and inclusion of the additional institutional co-variates that are included in the baseline aggregate specification of the previous section (results available from the author upon request).

${ }^{35}$ In addition, I have also examined the impact of minimum wages on the persistence of shocks and found no significant effect.
} 
the evidence also suggests that these policies risk prolonging the effects of adverse aggregate shocks. But the estimates presented in this paper show that the dampening effect outweighs the persistence effect and employment protection for regular workers is likely to reduce the cumulated loss of labour income brought about by a downturn. This suggests that policymakers should set their stance, as regards labour regulation, by striking a balance between the gains in efficiency associated with lower employment protection (see Bassanini al., 2009) and the labour-income smoothing associated with higher employment protection. 


\section{References}

Abraham, K.G., Haltiwanger, J.C. , 1995. Real Wages over the Business Cycle. Journal of Economic Literature 33, 1215-1264.

Amisano, G., Serrati, M. , 2003. What Goes Up Sometimes Stays Up: Shocks and Institutions as Determinants of Unemployment Persistence. Scottish Journal of Political Economy 50.

Angrist, J.D., Pischke, J.S., 2009. Mostly Harmless Econometrics. Princeton University Press, Princeton.

Babecký, J., Du Caju, P., Kosma, T., Lawless, M., Messina, J., Rõõm, T., 2009. Nominal and Real Rigidity: Survey Evidence from European Firms. ECB Working Paper No. 1105.

Babecký, J., Du Caju, P., Kosma, T., Lawless, M., Messina, J., Rõõm, T., 2010. Why Firms Avoid Cutting Wages: Survey Evidence from European Firms. Presentation at the OECD ELSA Seminar Series, Paris, October 2010.

Balakrishnan, R., Michelacci, C., 2001. Unemployment Dynamics Across OECD Countries. European Economic Review 45, 135-165. doi:10.1016/S0014-2921(99)00064-1

Baldwin, J., 2009. A Note on the Labour Data and Capital Data for Canadian Industries in the EU KLEMS. Mimeo, Statistics Canada. Available online at www.euklems.net.

Balmaseda, M., Dolado, J., Lopez-Salido, J.D., 2000. The Dynamic Effects of Shocks to Labour Markets: Evidence from OECD Countries. Oxford Economic Papers 52, 3-23. doi:10.1093/oep/52.1.3

Bassanini, A., Duval, R., 2006. Employment Patterns in OECD Countries: Reassessing the Role of Policies and Institutions. OECD Social, Employment and Migration Working Paper no. 35. OECD Publishing.

Bassanini, A., Duval, R., 2009. Unemployment, Institutions, and Reform Complementarities: Re-Assessing the Aggregate Evidence for OECD Countries. Oxford Review of Economic Policy 25,40-59.

Bassanini, A., Garnero, A., 2010. Dismissal Protection and Worker Flows in OECD Countries: Evidence from Cross-Country/Cross-Industry Data. IZA Discussion Paper 6535.

Bassanini, A., Garnero, A., Marianna, P., Martin, S., 2010. Institutional Determinants of Worker Flows: A Cross-Country/Cross-Industry Approach. OECD Social, Employment and Migration Working Paper No. 107. OECD Publishing, OECD. 
Bassanini, A., Nunziata, L., Venn, D., 2009. Job Protection Legislation and Productivity Growth in OECD Countries. Economic Policy 58, 349-402. doi:10.1111/j.1468-0327.2009.00221.x

Bassanini, A., Venn, D., 2007. Assessing the Impact of Labour Market Policies on Productivity: A Difference-in-Differences Approach. OECD Social, Employment and Migration Working Papers No. 54. OECD Publishing, OECD.

Baxter, M., King, R.G., 1999. Measuring Business Cycles: Approximate Band-Pass Filters For Economic Time Series. Review of Economics and Statistics 81, 575-593. doi:10.1162/003465399558454

Bentolila, S., Bertola, G., 1990. Firing Costs and Labour Demand: How Bad Is Eurosclerosis? Review of Economic Studies 57, 381-402. doi: $10.2307 / 2298020$

Bertola, G., 1990. Job Security, Employment, and Wages. European Economic Review 54, 851-879. doi:10.1016/0014-2921(90)90066-8

Bertola, G., 1999. Macroeconomic Perspectives on Aggregate Labor Markets. In Ashenfelter, O., Card, D. (Eds.),Handbook of Labor Economics, Vol. 3 Part C, pp. 2985-3028. doi:10.1016/S1573-4463(99)30036-5

Bertola, G., Rogerson, R., 1997. Institutions and Labor Reallocation. European Economic Review 41, 1147-1171. doi:10.1016/S0014-2921(96)00048-7

Bewley, T.F., Akerlof, G.A., Dickens, W.T., Perry, G.L., 2000. Near Rational Wage and Price Setting and the Long-run Phillips Curve. Brookings Papers on Economic Activity 1, 1-44.

Biagi, F., Lucifora, C., 2008. Demographic and Education Effects on Unemployment in Europe. Labour Economics 15, 1076-1101. doi:10.1016/j.labeco.2007.09.006

Blanchard, O., Wolfers, J., 2000. The Role of Shocks and Institutions in the Rise of European Unemployment: The Aggregate Evidence. Economic Journal 110, 1-33. doi:10.1111/1468-0297.00518

Boeri, T., van Ours, J., 2008. The Economics of Imperfect Labor Markets. Princeton University Press. Princeton.

Brandolini, A., 1995. In Search of a Stylised Fact: Do Real Wages Exhibit a Consistent Pattern of Cyclical Variability? Journal of Economic Surveys 9, 103-163. doi:10.1111/j.1467-6419.1995.tb00112.x

Burgess, S., Knetter, M., Michelacci, C., 2000. Employment and Output Adjustment in the OECD: A Disaggregate Analysis of the Role of Job Security Provisions. Economica 67, 419-435. doi:10.1111/1468-0335.00216 
Card, D., Chetty, R., Weber, A., 2007. The Spike at Benefit Exhaustion: Leaving the Unemployment System or Starting a New Job? American Economic Review Paper and Proceedings 97, 113-118. doi:10.1257/aer.97.2.113

Chetty, R., 2008. Moral hazArd Versus Liquidity and Optimal Unemployment Insurance. Journal of Political Economy 116, 173-234. doi:10.1086/588585

Cingano, F., Leonardi, M., Messina, J., Pica, G., 2010. The Effects of Employment Protection Legislation and Financial Market Imperfections on Investment: Evidence from a Firm-Level Panel of EU Countries. Economic Policy 61, 117-163. doi:10.1111/j.1468-0327.2009.00235.x

Devereux, P., 2001. The Cyclicality of Real Wages within EmployerEmployee Matches. Industrial and Labor Relations Review 54, 835-850. doi:10.2307/2696115

Devereux, P., Hart, R., 2007. Real Wage Cyclicality of Job Stayers, withinCompany Job Movers, and Between-Company Job Movers. Industrial and Labor Relations Review 60, 105-119.

Dickens, W., Goette, L., Groshen, E., Holden, S., Messina, J., Schweitzer, M., Turunen, J., Ward, M., 2007. How Wages Change: Micro Evidence from the International Wage Flexibility Project. Journal of Economic Perspectives 21, 195-214. doi:10.1257/jep.21.2.195

Draca M., Machin, S., van Reenen, J., 2011. Minimum Wages and Firm Profitability. American Economic Journal: Applied Economics 3, 129-151. doi:10.1257/app.3.1.129

Dromel, N., Pintus, P., 2008. Are Progressive Income Taxes Stabilizing? Journal of Public Economic Theory 10, 329-349. doi:10.1111/j.14679779.2008.00365.x

Druant, M., Fabiani, S., Kezdi, G., Lamo, A., Martins, F., Sabbatini, R., 2009. How Are Firms' Wages and Prices Linked: Survey Evidence in Europe. ECB Working Paper No. 1084.

Dustmann, C., Glitz, A., Vogel, T., 2010. Employment, Wages, and the Economic Cycle: Differences between Immigrants and Natives. European Economic Review 54, 1-17. doi:10.1016/j.euroecorev.2009.04.004

Elsby, M.W.L., 2009. Evaluating the Economic Significance of Downward Nominal Wage Rigidity. Journal of Monetary Economics 56, 154-169. doi:10.1016/j.jmoneco.2008.12.003

Farber, H.S., 2005. What Do We Know about Job Loss in the United States? Evidence from the Displaced Workers Survey, 1984-2004. Princeton University Industrial Relations Section Working Papers, No. 498. 
Gottschalk, P., 2005. Downward Nominal-Wage Flexibility: Real or Measurement Error? Review of Economics and Statistics. 87, 556-568. doi:10.1162/0034653054638328

Guo, J.-T., Lansing, K., 1998. Indeterminacy and Stabilization Policy. Journal of Economic Theory 82, 481-490. doi:10.1006/jeth.1997.2446

Haltiwanger, J., Scarpetta, S., Schweiger, H., 2008. Assessing Job Flows across Countries: The Role of Industry, Firm Size and Regulations. NBER Working Paper No. 13920. Cambridge, Mass.

Heathcote, J., Perri, F., Violante, G.L., 2010. Unequal We Stand: An Empirical Analysis of Economic Inequality in the United States: 1967-2006. Review of Economic Dynamics 13, 15-51. doi:10.1016/j.red.2009.10.010

Hijzen, A., Venn, D., 2010. The Role of Short-Time Work Schemes During the 2008-09 Recession. OECD Social, Employment and Migration Working Paper No. 115. OECD Publishing, OECD.

Hodrick, R.J., Prescott, E.C., 1997. Postwar U.S. Business Cycles: An Empirical Investigation. Journal of Money, Credit and Banking 29, 1-16. doi: $10.2307 / 2953682$

Jacobson, L.S., LaLonde, R.J., Sullivan, D.G., 1993. Earnings Losses of Displaced Workers. American Economic Review 83, 685-709.

Kandil, M., 2010. Demand Shocks and the Cyclical Behavior of the Real Wage: Some International Evidence. Journal of Applied Economics 13, 135158. doi:10.1016/S1514-0326(10)60007-4

Krebs, T., 2007. Job Displacement Risk and the Cost of Business Cycles. American Economic Review 97, 664-686. doi:10.1257/aer.97.3.664

Krueger, A.B., Mueller, A., 2010. Job Search and Unemployment Insurance: New Evidence from Time Use Data. Journal of Public Economics 94, 298307. doi:10.1016/j.jpubeco.2009.12.001

Messina, J., Du Caju, P., Duarte, C., Hansen, N., Izquierdo, M., 2010. The Incidence of Nominal and Real Wage Rigidity: an Individual-Based Sectoral Approach. Journal of the European Economic Association 8, 487-496.

Messina, J., Strozzi, C., Turunen, J., 2009. Real Wages over the Business Cycle: OECD Evidence from the Time and Frequency Domains. Journal of Economic Dynamics and Control 33, 1183-1200. doi:10.1016/j.jedc.2008.11.005

Micco, A., Pages, C., 2006. The Economic Effects of Employment Protection: Evidence from International Industry-Level Data. IZA Discussion Paper No. 2433. Bonn. 
Mortensen, D., Pissarides, C.A., 1999. Unemployment Responses to 'Skill Biased' Shocks: The Role of Labor Market Policy. Economic Journal 109, 242-265. doi:10.1111/1468-0297.00431

Nickell, S., Nunziata, L., Ochel, W., 2005. Unemployment in the OECD Since the 1960s: What Do We Know? Economic Journal 115, 1-27. doi:10.1111/j.1468-0297.2004.00958.x

Nickell, S., Quintini, G., 2003. Nominal Wage Rigidity and the Rate of Inflation. Economic Journal 113, 762-781. doi:10.1111/1468-0297.t01-1-00161

OECD (2006), Employment Outlook, OECD Publishing, Paris

OECD (2009), Employment Outlook, OECD Publishing, Paris

OECD (2010), Employment Outlook, OECD Publishing, Paris.

OECD (2011), Employment Outlook, OECD Publishing, Paris.

Ormerod, P., 2010. Resilience after Local Economic Shocks. Applied Economics Letters 17, 503-507. doi:10.1080/13504850801964331

Pissarides, C., 2009. The Unemployment Volatility Puzzle: Is Wage Stickiness the Answer? Econometrica 77, 1339-1369. doi:10.3982/ECTA7562

Porter, N., Vitek, F., 2008. The Impact of Introducing a Minimum Wage on Business Cycle Volatility. IMF Working Paper No. 08-285.

Rajan, R., Zingales, L., 1998. Financial Dependence and Growth. American Economic Review 88, 559-586.

Robin, J.M., 2011. On the Dynamics of Unemployment and Wage Distributions. Econometrica, forthcoming.

Schmieder, J.F., von Wacher, T., Bender, S., 2010. The Long-term Impact of Job Displacement in Germany During the 1982 Recession on Earnings, Income, and Employment. IAB Discussion Paper, No. 1/2010.

Subramanian K., Megginson, W.L., 2011. Employment Protection Laws and Privatization. Mimeo, University of Oklahoma. Available online at http://papers.ssrn.com.

Timmer, M., van Moergastel, T., Stuivenwold, E., Ypma, G., O’Mahony, M., Kangasniemi, M., 2007. EU KLEMS growth and productivity accounts Version 1.0: Part 2: Sources by country. Mimeo, GGDC and NIESR. Available online at www.euklems.net. 


\section{Appendix: Data Construction, Sources and Descrip- tive Statistics}

\section{Industry-level Data}

Earnings and hourly wage data refer to total gross annual earnings and average hourly wages, respectively of wage and salary employees. Employment refers to annual averages for wage and salary employees. Hours worked refers to total annual hours for the same employees. Real value added is obtained by deflating nominal value added in each industry with the industry-specific double deflator. Data are from the EUKLEMS Database except for Norway, where they come from the OECD STAN Database and refer to total employment. EUKLEMS data obtained through interpolation and/or estimated on the basis of conjectures, identified from Timmer et al. (2007), Baldwin (2009) and the related EUKLEMS documentation, were removed from the sample. Data are aggregated at the level of the business sector to be used in aggregate regressions. The list of industries used in the industry-level analysis is reported in Table A1.

The distributions by educational attainment of earnings, wage, and hours also come from the EUKLEMS database. Again, data obtained through interpolation and/or on the basis of conjectures were removed from the sample. Education is divided into three categories: low-education (less than upper secondary); medium education (upper secondary); and high education (more than upper secondary). The business sector, in this case, is partitioned in 9 industries for reasons of data reliability (refer to ISIC codes reported in Table A1): 10-14 and 40-41; 15-19 and 36-37; 20-28; 29-35; 45; 50-52 and 55; 60-64; 65-67; and 70-74.

The industry-specific US dismissal rate is from Bassanini et al. (2010; www.oecd.org/dataoecd/28/30/46825863.zip) and is derived from various waves of the CPS Displaced Workers Supplement (2000-2006, even years). An individual is considered to have been dismissed if he/she lost his/her job in the most recent year covered by each survey, because of plant closing or moved, insufficient work, or position or shift abolished. Only wage and salary employees in the private-for-profit sector are considered.

The share of low-paid workers in the United Kingdom prior to the introduction of the minimum wage in 1999 is the average share of low-pay workers in each industry over all available quarters between 1994 and 1998. In each quarter, low-paid workers are defined as those with gross hourly wages less than two-thirds of the median wage of the quarter for the whole economy. The source is the UK Labour Force Survey.

Wage indexation is the employment-weighted share of firms having a policy of adjusting base wage to inflation in 2007-2008. Data are disaggregated into five industries and were kindly provided by the WDN and the 
Table A1 - List of Industries (with ISIC rev. 1 code)

\begin{tabular}{cl} 
Isic Rev.1 code & \multicolumn{1}{c}{ Industry label } \\
\hline $10-14$ & Mining \\
$15-16$ & Food, beverages and tobacco \\
$17-19$ & Textiles, leather and footwear \\
20 & Wood and manufacturing of wood and cork \\
$21-22$ & Pulp, paper, printing and publishing \\
23 & Coke, refined petroleum and nuclear fuel \\
24 & Chemicals and chemical products \\
25 & Rubber and plastics \\
26 & Other non-metallic mineral products \\
$27-28$ & Basic metals and fabricated metal \\
29 & Machinery, not elsewhere classified \\
$30-33$ & Electrical and optical equipment \\
$34-35$ & Transport equipment \\
$36-37$ & Other manufacturing; Recycling \\
$40-41$ & Electricity, gas and water supply \\
45 & Construction \\
$50-52$ & Wholesale and retail trade \\
55 & Hotels and restaurants \\
$60-63$ & Transport and storage \\
64 & Post and telecommunications \\
$65-67$ & Financial intermediation \\
70 & Real estate activities \\
$71-74$ & Other business services \\
& \\
\end{tabular}

Table A2 - Summary Statistics, Industry-level Variables, Main Sample

\begin{tabular}{lccccc}
\hline Variable & Observations & Mean & Std. Dev. & Min & Max \\
\hline Log earnings gap & 8998 & 0.001144 & 0.057396 & -0.88136 & 0.489028 \\
Log wage gap & 8998 & 0.000187 & 0.04373 & -0.90662 & 0.560124 \\
Log hours gap & 8998 & 0.000991 & 0.049829 & -0.39632 & 0.5378 \\
Log employment gap & 8998 & 0.000614 & 0.049404 & -0.50383 & 0.459586 \\
Log value added gap & 8568 & 0.00124 & 0.086022 & -1.32804 & 1.265822 \\
US layoff rate & 8604 & 5.18404 & 1.6671 & 2.226535 & 8.995686 \\
UK low pay rate & 8998 & 0.144562 & 0.084716 & 0.032433 & 0.390982 \\
Wage indexation & 2966 & 50.19957 & 29.07121 & 0 & 100 \\
\hline
\end{tabular}

ECB. The source is Druant et al. (2009).

Table A2 reports summary statistics of the main industry-level variables.

\section{Institutional Variables}

EP indicators come from the OECD Indicators of Employment Protection (www.oecd.org/employment/protection). All indicators vary from 0 to 6 from 
the least to the most stringent. In aggregate regressions, data are extended backward by making them constant between 1978 and 1985 .

UB generosity is measured on the basis of average replacement rates (in percent of pre-displacement wage), defined as average unemployment benefit replacement rate across two income situations $(100 \%$ and $67 \%$ of average worker earnings), three family situations (single, with dependent spouse, with spouse in work) and three different unemployment durations (first year, second and third years, and fourth and fifth years of unemployment). Net benefits, available between 2001 and 2007, are net of taxes and transfers, but exclude means-tested social assistance. The source is the OECD Benefits and Wages database (www.oecd.org/els/social/workincentives).

The indexes of anti-competitive product market regulation come from the OECD Regulatory Database (www.oecd.org/document/1/0,3746,en_2649_37 4212367297_1_1_1_37421,00.html). They vary from 0 to 6 from the least to the most restrictive. Time-invariant aggregate regulation data refer to 1998. Time-varying aggregate data are based on two 1-digit industries (Energy and Transport and Communications).

Minimum wages are measured as the ratio of the statutory minimum wage to median wage of full-time workers. For exogeneity tests, the deviation of the logarithm of the real minimum wage in 2000 USD purchasing power parities from the OECD average of each year is used an instrument. The source of all these variables is the OECD Employment Database (www.oecd.org/els/employment/database).

The tax wedge considered in this paper is the wedge between the labour cost for the employer and the corresponding net take-home pay of the employee for single-earner couples with two children earning $100 \%$ of average worker earnings. It is expressed as the sum of personal income tax and all social security contributions as a percentage of total labour cost. Data are retropolated using tax wedges for average production workers between 1978 and 1982 for most countries. Data on marginal tax rates are available for eight income levels and family situations from 2000 to 2007. These rates refer to the marginal tax of the principal earner in the following situations: single person at $167 \%$ of average earnings and no child; Single person at $100 \%$ of average earnings and no child; two-earner married couple, one at $100 \%$ of average earnings and the other at $33 \%$, with no child; two-earner married couple, one at $100 \%$ of average earnings and the other at $67 \%$, with two children; two-earner married couple, one at $100 \%$ of average earnings and the other at $33 \%$, with two children; single person at $67 \%$ of average earnings, with two children; one-earner married couple at $100 \%$ of average earnings, with two children; single person at $67 \%$ of average earnings, no child. The first four in the above are defined as relatively high income levels for the purpose of the analysis of this paper. Indicators of the level of average marginal tax rates on labour income are obtained by simple average of the different components. The source of all these variables is the OECD 
Taxing Wages Database (www.oecd.org/ctp/taxingwages).

Collective bargaining coverage is the share of workers covered by a collective agreement, in percentage. The source is the ICTWSS database ( $h t t p: / /$ www.uva-aias.net/207). Data were averaged or interpolated when information is not available at the annual level.

The degree of corporatism is proxied with two mutually exclusive variables. The BD index takes values 1 for decentralised and uncoordinated wage-bargaining processes, and 2 and 3 for intermediate and high degrees of centralisation/co-ordination, respectively. Data were extended to cover the period 2003-2007. The source is Bassanini and Duval (2009; www.oecd.org/ dataoecd/25/25/37431112.zip). Alternatively, the ICTWSS index of coordination is used, which takes values from 1 to 5 from the least to the most coordinated. The source of this variable is the ICTWSS database (http://www.uvaaias.net/207).

The presence of short-time work scheme, used in a few robustness checks, is codified through a dummy for existence of these schemes in 2007. The source is Hijzen and Venn (2010).

\section{Other aggregate variables}

The output gap is the OECD measure of the gap between actual and potential output as a percentage of potential output. In the case of Korea, due to the lack the OECD measure of the output gap, an HP filter of GDP in volume terms is used to derive the output gap. The source is OECD Economic Outlook (EO) database.

Earnings and wage data are deflated using the private consumption deflator, drawn from the OECD EO Database

The aggregate share of temporary workers is drawn from labour force surveys. Missing years were interpolated. Temporary workers are those whose job's termination is determined by objective conditions such as reaching a certain date, completion of an assignment or return of another employee who has been temporarily replaced. Included in these groups also are: a) persons with a seasonal job; b) persons engaged by an employment agency or business and hired out to a third party for the carrying out of a "work mission" (unless there is a work contract of unlimited duration with the employment agency or business); and c) persons with specific training contracts. The source is the OECD Employment Database (www.oecd.org/els/employment/database).

Table A3 reports summary statistics of the main aggregate variables. 
Table A3 - Summary Statistics, Main Aggregate Variables

\begin{tabular}{lccccc}
\hline Variable & Observations & Mean & Std. Dev. & Min & Max \\
\hline Log earnings gap & 531 & -0.00029 & 0.038413 & -0.14573 & 0.155526 \\
Log wage gap & 531 & -0.00059 & 0.020864 & -0.076 & 0.086785 \\
Log hours gap & 531 & 0.000305 & 0.029727 & -0.12681 & 0.105689 \\
Output gap & 539 & -0.00191 & 0.02113 & -0.08676 & 0.064828 \\
EP & 539 & 2.124898 & 1.004258 & 0.21 & 4.1 \\
EPR & 449 & 2.16029 & 0.907506 & 0.17 & 4.83 \\
EPT & 449 & 2.042739 & 1.401948 & 0.25 & 5.38 \\
ARR (gross) & 516 & 28.47152 & 13.70659 & 0.347222 & 64.94407 \\
ARR (net, average) & 539 & 40.77312 & 20.74327 & 5.654741 & 67.16872 \\
PMR (time-varying) & 539 & 3.70764 & 1.346185 & 0.938546 & 6 \\
PMR (time-invariant, 98) & 539 & 2.019111 & 0.573705 & 1.0698 & 3.969725 \\
Minimum wage & 319 & 0.456871 & 0.101906 & 0.2185 & 0.6745 \\
Average tax wedge & 473 & 29.69772 & 9.438382 & 1.918403 & 60.81406 \\
Marginal tax wedge on high & 539 & 48.85163 & 9.547817 & 24.32234 & 67.5211 \\
incomes (average) & & & & \\
Bargaining coverage & 481 & 67.87409 & 24.86884 & 10 & 99 \\
Corporatism (BD) & 524 & 2.227099 & 0.865722 & 1 & 3 \\
Corporatism (ICTWSS) & 524 & 3.139313 & 1.358234 & 1 & 5 \\
STW scheme & 526 & 0.749049 & 0.433973 & 0 & 1 \\
Year & 539 & 1994.356 & 8.223821 & 1979 & 2007 \\
\hline
\end{tabular}

